\title{
Chemical and Biological Significance of Oenothein B and Related Ellagitannin Oligomers with Macrocyclic Structure
}

\author{
Takashi Yoshida ${ }^{1,2}$, Morio Yoshimura ${ }^{1}$ and Yoshiaki Amakura ${ }^{1, *}$ \\ 1 College of Pharmaceutical Sciences, Matsuyama University, 4-2 Bunkyo-cho, Matsuyama, Ehime 790-8578, \\ Japan; xp769b@bma.biglobe.ne.jp (T.Y.); myoshimu@g.matsuyama-u.ac.jp (M.Y.) \\ 2 Okayama University, Okayama 701-1152, Japan \\ * Correspondence: amakura@g.matsuyama-u.ac.jp; Tel.: +81-89-925-7111
}

Received: 5 February 2018; Accepted: 26 February 2018; Published: 2 March 2018

\begin{abstract}
In 1990, Okuda et al. reported the first isolation and characterization of oenothein B, a unique ellagitannin dimer with a macrocyclic structure, from the Oenothera erythrosepala leaves. Since then, a variety of macrocyclic analogs, including trimeric-heptameric oligomers have been isolated from various medicinal plants belonging to Onagraceae, Lythraceae, and Myrtaceae. Among notable in vitro and in vivo biological activities reported for oenothein B are antioxidant, anti-inflammatory, enzyme inhibitory, antitumor, antimicrobial, and immunomodulatory activities. Oenothein B and related oligomers, and/or plant extracts containing them have thus attracted increasing interest as promising targets for the development of chemopreventive agents of life-related diseases associated with oxygen stress in human health. In order to better understand the significance of this type of ellagitannin in medicinal plants, this review summarizes (1) the structural characteristics of oenothein B and related dimers; (2) the oxidative metabolites of oenothein B up to heptameric oligomers; (3) the distribution of oenotheins and other macrocyclic analogs in the plant kingdom; and (4) the pharmacological activities hitherto documented for oenothein B, including those recently found by our laboratory.
\end{abstract}

Keywords: oenothein B; ellagitannin; macrocyclic oligomer; Onagraceae; Myrtaceae; Lythraceae; antioxidants; antitumor effect; immunomodulatory effect; anti-inflammation

\section{Introduction}

Antioxidant polyphenols in medicinal plants, foods, and fruits are currently acknowledged as important beneficial constituents that reduce the risk of life-related diseases closely associated with active oxygen damage, such as cancers, arteriosclerosis, diabetes, and coronary heart diseases, and have been explored as plausible chemopreventive agents for the human healthcare market. Polyphenols have thus received increasing attention for the discovery and development of their new physiological functions. Among various types of antioxidant plant polyphenols are low molecular weight compounds, represented by flavonoids and lignans, and higher molecular weight polyphenols classified as tannins. Vegetable tannins are classified into two large groups: (1) condensed tannins (proanthocyanidin polymers and oligomers); and (2) hydrolysable tannins, which are subgrouped into gallotannins (polygalloyl esters of glucose) and ellagitannins, which are characterized as hexahydroxydiphenoyl (HHDP) esters of sugar, mostly glucose, as represented by geraniin (1), tellimagrandin I (2), and II (3). In contrast to condensed tannins and gallotannins (Turkish or Chinese gall), which were long recognized in the leather industry [1], ellagitannins in medicinal plants had been little studied before the discovery of geraniin (1) from a Japanese folk medicine, Geranium thunbergii (Geraniaceae), by Okuda's group in 1976 [2,3]. Since 1976, 
remarkable progress in the field of ellagitannin chemistry, promoted by the development of high resolution NMR and MS spectrometers and new separation methods, has led to the isolation and characterization of more than 500 ellagitannins with diverse arrays of structures from the traditional medicines long used in Japan, China, and South East Asia. The structural diversity of the ellagitannins are brought by various oxidative modifications of the HHDP group producing dehydroellagitannins, such as $\mathbf{1}$ or by intermolecular $\mathrm{C}-\mathrm{O}$ oxidative coupling(s) among multiple molecules, leading to oligomeric ellagitannins [4-7]. The first dimeric ellagitannin encountered in nature was agrimoniin from Agrimonia pilosa (Rosaceae), which was characterized as a dimer of potentillin (1-O-galloyl-2,3/4,6-di-O-(S)-HHDP- $\alpha$-D-glucose), produced through the formation of a dehydrodigalloyl linking unit by intermolecular $\mathrm{C}-\mathrm{O}$ oxidative coupling between two galloyl groups at C-1 [8]. Among the more than 300 oligomers, up to heptamer, reported after the discovery of agrimoniin, oenothein B (4) is a unique macrocyclic ellagitannin dimer, which is biogenetically produced by double C-O couplings of two molecules of tellimagrandin I (2), as illustrated in Figure 1.
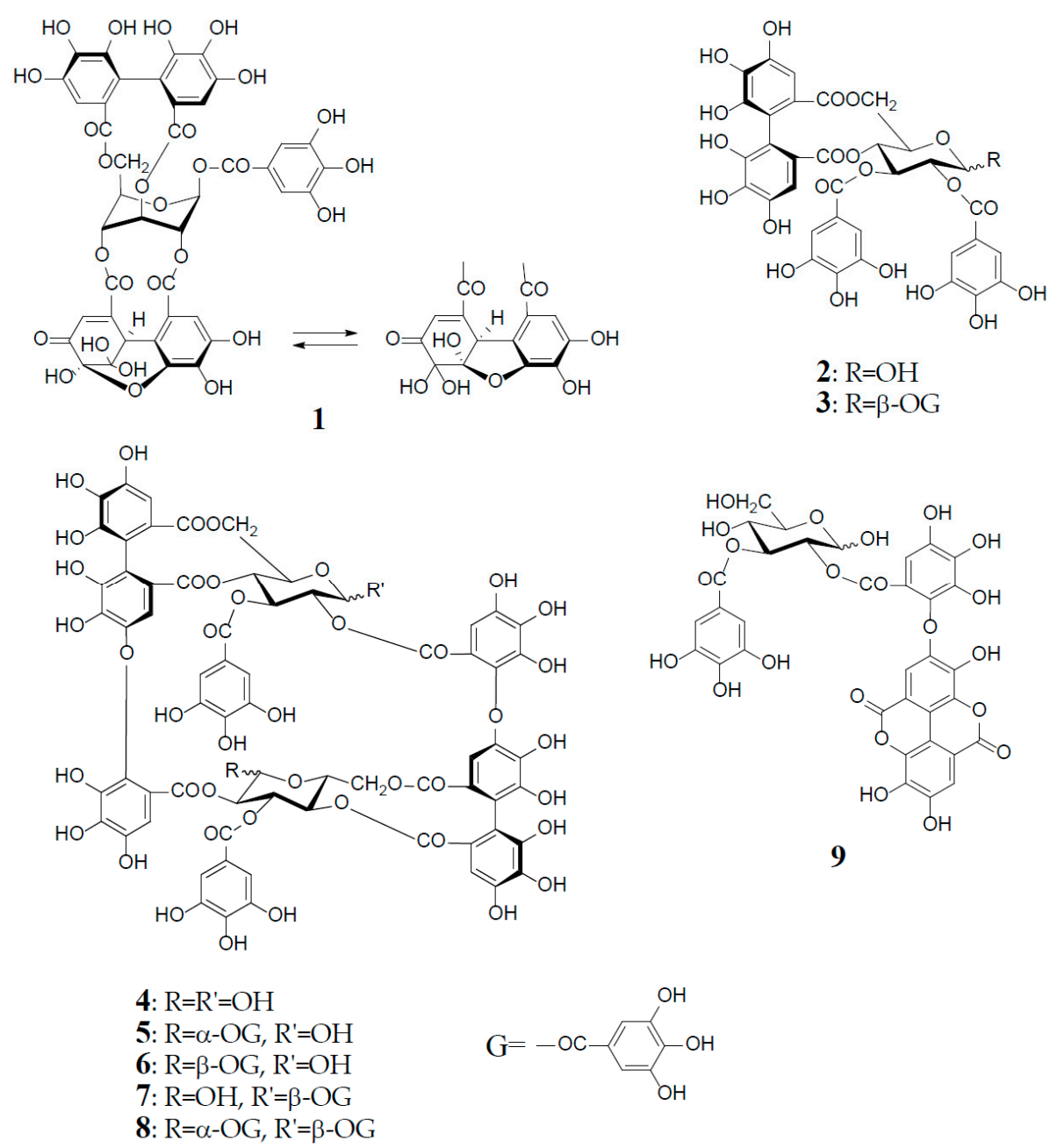

Figure 1. Structures of geraniin (1), tellimagrandin I (2), and II (3), oenothein B (4), woodfordin C (5), eugeniflorin $\mathrm{D}_{1}(6)$, cuphiin $\mathrm{D}_{2}(7)$, cuphiin $\mathrm{D}_{1}(8)$, and oenothein $\mathrm{C}(9)$.

Oenothein B (4) was first isolated as a major component from the leaves of Oenothera erythrosepala (Onagraceae) in 1990 [9], and later found widely distributed in other plant species belonging to Myrtaceae and Lythraceae, as well as Onagraceae $[5,6,10,11]$. It was an important leading compound that made easier the structure elucidation of analogous oligomers co-occurring in various plant species. 
Furthermore, oenothein B and related oligomers have been reported to exhibit a variety of in vitro or in vivo physiological activities beneficial to human health.

This review summarizes the structural characteristics of oenothein B (4) and related oxidized metabolites, up to heptameric oligomer, found in medicinal plants and their diverse biological functions hitherto reported, including those discovered recently in our laboratory. This review provides a better understanding of the significance of those antioxidant tannin constituents in medicinal plants, which may lead to future developments of preventive or therapeutic agents for various chronic diseases associated with oxygen stress by active oxygen species and free radicals.

\section{Structural Characteristics of Oenothein B}

Oenothein B (4), FABMS $m / z 1569[\mathrm{M}+\mathrm{H}]^{+}$, was obtained as an amorphous powder forming an inseparable mixture of theoretically four anomers at two C-1 unacylated glucosyl cores, which caused extreme difficulty in its structure elucidation by spectroscopic analysis. In fact, the ${ }^{1} \mathrm{H}-\mathrm{NMR}$ spectrum in acetone- $d_{6}-\mathrm{D}_{2} \mathrm{O}$ recorded at ambient temperature is poorly informative due to severe broadening and multiplication of each proton signal. This spectral feature is characteristic of this type of macrocyclic oligomers owing to the anomerization at each glucose core, and also to a poor flexibility of the macro ring arising from a restricted rotation around the ether linkages of two valoneoyl groups. The structure determination of 4 was performed by spectral and chemical methods, briefly described below.

The ${ }^{1} \mathrm{H}-\mathrm{NMR}$ measurement at an elevated temperature $\left(40-50{ }^{\circ} \mathrm{C}\right)$ provided a more informative spectrum, indicating the presence of a predominant anomer with anomeric proton signals at $\delta 6.20$ $(\mathrm{d}, J=3.5 \mathrm{~Hz})$ and $\delta 4.48(\mathrm{~d}, J=7.5 \mathrm{~Hz})$, due to the $\alpha$ - and $\beta$-anomers of glucose-I and II, respectively; however, some of the aromatic and sugar proton signals still broadened, probably due to the poor flexibility of the macro ring. A conclusive clue for the structure elucidation of 4 was brought by the $\mathrm{NaBH}_{4}$ reduction at the anomeric centers, which gave a sole tetrahydro derivative with two glucitol cores showing a well-resolved simple NMR spectrum. The spectrum clearly indicated the presence of two each of valoneoyl, galloyl, and glucitol groups as components, as revealed by the characteristic six $1 \mathrm{H}$-singlets and two $2 \mathrm{H}$-singlets in the aromatic region. These units were chemically substantiated by acid hydrolysis of 4 , which produced glucose, and by permethylation followed by methanolysis, which afforded methyl tri-O-methylgallate and trimethyl (S)-octa-O-methylvaloneate in a 1:1 molar ratio. The binding modes of the valoneoyl and galloyl groups on the glucose cores in 4 were determined from the long-range ${ }^{1} \mathrm{H}^{-13} \mathrm{C}$ shift correlation spectrum of the tetrahydro derivative and identification of partial hydrolysates, including oenothein C (9), obtained upon treatment of 4 with hot water. The ${ }^{13} \mathrm{C}-\mathrm{NMR}$ and CD (large positive Cotton effect at 218-236 nm) spectra of oenothein B were all consistent with the gross structure (4) [9] (Figure 1).

It is noteworthy that the purity of oenothein B (4) is hard to assess by reversed-phase HPLC, because of the appearance of multiple peaks on the chromatograph, depending on the different ratio of the anomers. The LC-MS/MS data for oenothein B reported by Toth et al. might be valuable for its identification [11]. Although expensive, oenothein B is now commercially available as analytical standard, and thus can be used as reference compound for the identification of oenothein B isolated from natural sources, by comparisons of the normal and reversed-phases HPLC with those of the commercial reagent.

Among interesting analogs of oenothein B (4) are oenotheins D (10) and F (11), which were isolated together with $\mathbf{4}$ (major principle) from the leaves of Oenothera laciniata, and characterized as regioisomers of 4, differing at the binding site of the valoneoyl group linking each monomeric unit, as illustrated in Figure 2 [12]. Contrary to oenothein B (4), oenothein D (10) displayed a well-resolved ${ }^{1} \mathrm{H}-\mathrm{NMR}$ spectrum at ambient temperature, and indicated the presence of predominant anomers at each glucose core, as revealed by the unacylated anomeric proton signals at $\delta 5.89(\mathrm{~d}, J=4 \mathrm{~Hz}$; glucose-I) and $4.85(\mathrm{~d}, \mathrm{~J}=8 \mathrm{~Hz}$; glucose-II). The positions of the two valoneoyl moieties in 10 were 
determined in a similar way to 4 , i.e., long-range ${ }^{1} \mathrm{H}^{-13} \mathrm{C}$ correlation spectrum and partial degradation in hot water.

The ${ }^{1} \mathrm{H}-\mathrm{NMR}$ spectrum of oenothein $\mathrm{F}(\mathbf{1 1})$ in acetone- $d_{6}-\mathrm{D}_{2} \mathrm{O}(2$ drops) indicated that it exists as a mixture of four anomers at the glucose cores, as shown by the valoneoyl $1 \mathrm{H}$ - and galloyl $2 \mathrm{H}$-singlets, each forming four lines in a ratio of ca. 1:2:2:6. It is noteworthy that the relative peak intensity of the four lines for each proton signal changed to ca. 1:4:4:23 after leaving the NMR sample in solution for two days. The ${ }^{1} \mathrm{H}-\mathrm{NMR}$ spectrum of the most dominant anomer looked like that of a monomeric tannin, namely the appearance of three singlets $(\delta 6.21,6.40$, and 7.30 , each $2 \mathrm{H})$ and one singlet $(\delta 7.04$, $4 \mathrm{H})$ assignable to two valoneoyl and two galloyl units. The sugar proton signals were also apparently those of a monomeric tannin closely similar to those of an $\alpha$-anomer of tellimagrandin I (2). Such a monomer-like ${ }^{1} \mathrm{H}-\mathrm{NMR}$ spectrum suggested that $\mathbf{1 1}$ has a symmetrical structure with a considerably flexible macro ring (Figure 2).

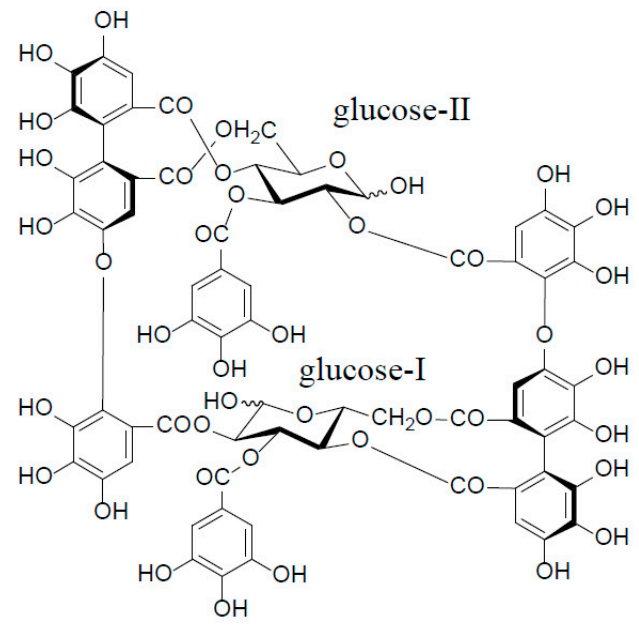

10

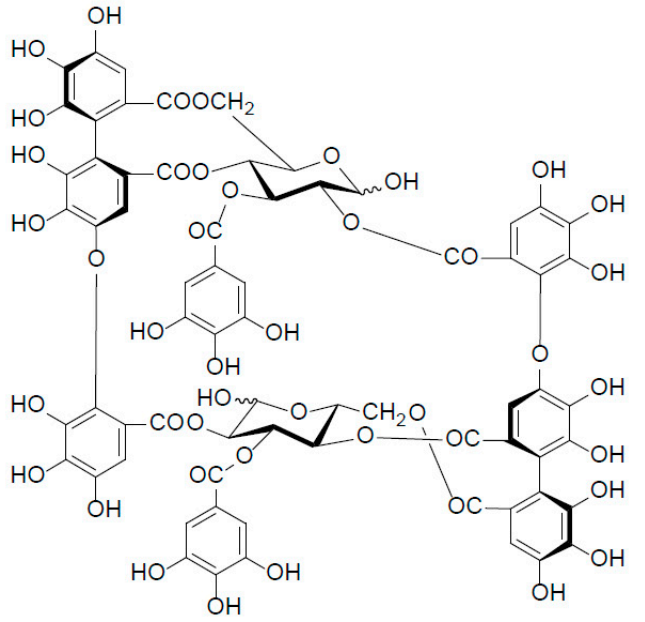

11

Figure 2. Structures of oenotheins D (10) and F (11).

Oenothein B (4) and related dimers were also found in plant species of Lythraceae and Myrtaceae, as well as Oenotheraceae. Notably, the lythraceous and myrtaceous plants, unlike Oenotheraceae, produce the galloylated oenothein B together with 4 . Woodfordin $C(5)$ and eugeniflorin $D_{1}(6)$, which are monogalloyl isomers at glucose-I of 4, were obtained from Woodfordia fruticosa (Lythraceae), a popular traditional Jamu medicine in Indonesia and Malaysia [13,14], and Eugenia uniflora (Myrtaceae), an evergreen fruit tree called Brazilian cherry [15], respectively. The ${ }^{1} \mathrm{H}-\mathrm{NMR}$ spectrum of 5 ( $\alpha$-gallate at glucose-I), recorded at ambient temperature, displayed broad signals for some of the aromatic and glucose protons, while the spectrum recorded at an elevated temperature $\left(38^{\circ} \mathrm{C}\right)$, which largely contributed to its structure elucidation, was much simpler, and displayed a preferred $\beta$-anomer at glucose-II [anomeric proton, $\delta 4.38$ (br. $\mathrm{d}, J=8 \mathrm{~Hz}$ )] [13]. Cuphiin $\mathrm{D}_{2}(7)$, a $\beta$-gallate at glucose-II of 4 , was isolated along with a digallate, cuphiin $\mathrm{D}_{1}(8)$, as well as 4 and 5 from the aerial parts of Cuphea hyssopifolia (Lythraceae), which has been used as a folk medicine for treating stomach disorders and oral contraceptive in South and Central Americas [16]. The existence of a dominant $\alpha$-anomer at glucose-I in $7(\delta 6.18, \mathrm{~d}, J=3 \mathrm{~Hz})$ was evidenced by the absence of duplicates of any proton signal in the NMR spectra recorded at $40^{\circ} \mathrm{C}$, and also the observation of a single peak in the reversed-phase HPLC. The structural relationship of cuphiins $\mathrm{D}_{1}(8)$ and $\mathrm{D}_{2}(7)$ was verified by enzymatic degalloylation of 8 , with tannase affording 4,5 , and 7 , besides gallic acid (Figure 1 ). 


\section{Oxidized Metabolites (Dimers and Oligomers) of Oenothein B}

An old hypothetical biogenesis of ellagitannins $[1,4,17]$ has now been proven by the intensive enzymatic studies of Gross et al. Using crude enzyme preparations from the Tellima grandiflora leaves, they demonstrated the in vitro biosynthesis of ellagitannins, which includes an intramolecular $\mathrm{C}-\mathrm{C}$ oxidative coupling of pentagalloylglucose to tellimagrandin II (3) [18], followed by an oxidative intermolecular $\mathrm{C}-\mathrm{O}$ coupling between two moles of 3 to yield a dimeric ellagitannin, cornusiin $\mathrm{E}$ (12) [19] (Figure 3). These in vitro C-C and C-O couplings in the biosynthesis of hydrolysable tannins are thought to occur in vivo through free radical coupling processes involving laccase-type phenolase, with a lower redox potential than those concerned in lignification processes.

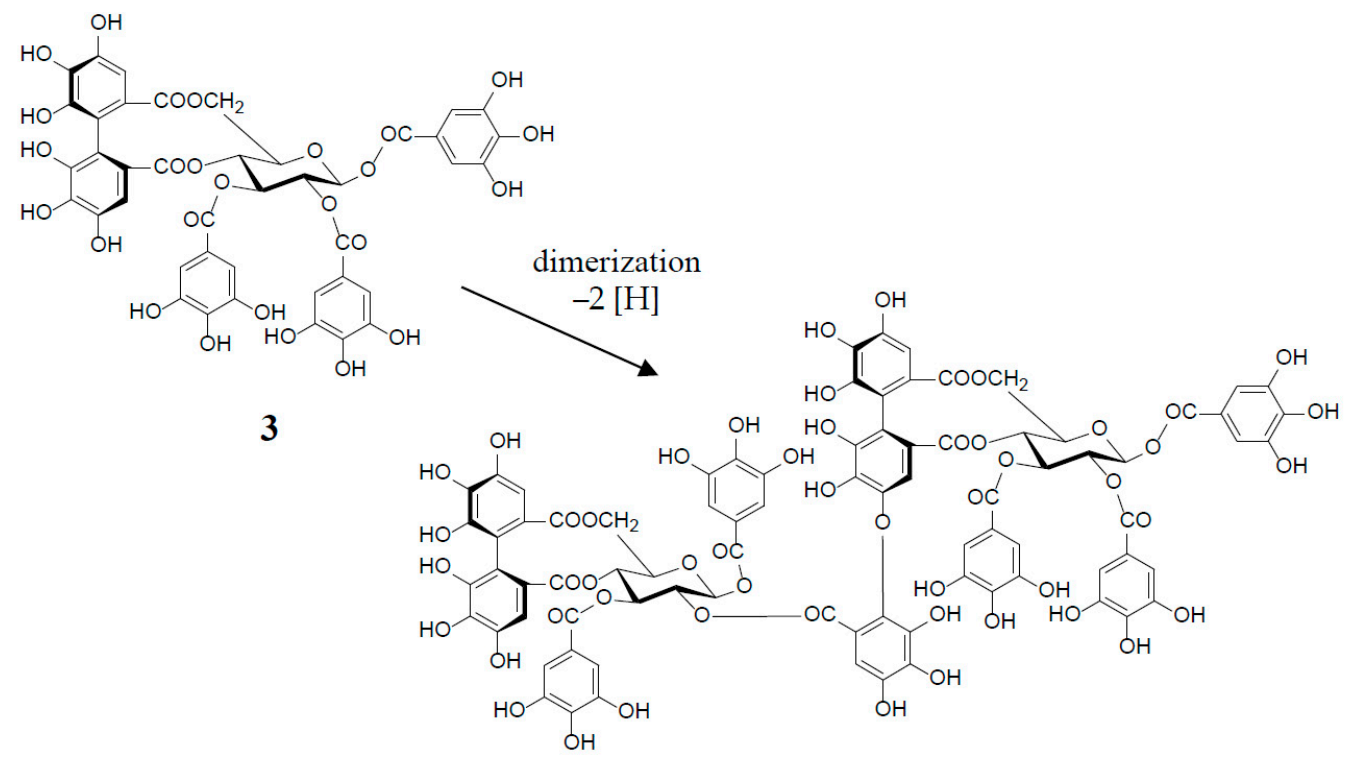

12

Figure 3. in vitro biosynthesis of cornusiin E (12) from tellimagrandin II (3) (2 moles).

Similar intermolecular oxidative coupling(s) of oenothein B and related dimers with additional monomeric ellagitannin(s) are believed to lead to trimeric and higher oligomeric analogs. Such examples in nature are oenothein A (13) from Oenothera and Epilobium species, and its gallate, woodfordins D (14) (trimer) [20], E (15) (trimer) and F (16) (tetramer), together with woodfordin I (17) (dimer) from the W. fruticosa flowers [21]. The presence of oenothein B-related oligomers larger than 16 in Epilobium angustifolium (willowherb) was recently reported by Salminen et al. [22]. They isolated the oenothein B-based oligomers using preparative HPLC, and characterized them as oenothein B (4), oenothtein A (13), woodfordin F (16), and related pentameric (18) to heptameric (20) oligomers, chiefly based on the analysis of the fragmentation pattern in the ESI-microTOF-Q mass spectra (negative mode) (Figure 4). The structures of these oligomers were postulated as those produced by the formation of the valoneoyl group through sequential intermolecular oxidative coupling(s) of a galloyl unit at C2 of monomeric tellimagrandin I (2) with an HHDP unit of the terminal glucose-IV of woodfordin F (16). In the mass spectra, basic fragmentation occurred reversely through the sequential removal of a molecule of tellimagrandin I (2) by the oxidative cleavage of an ether bond of the valoneoyl unit from the terminal glucose core, leading to a fragment ion due to the remaining HHDP (o-quinone) ester part(s). Quantitative analyses of individual oligomers in the extracts of flowers, leaves, and stems of E. angustifolium were successfully performed by ultra-high performance liquid chromatography coupled with tandem mass spectra (UHLC-MS/MS) [22,23]. This analytical method was reported to offer the advantages of good repeatability and sensitivity for an accurate quantification of this class of oligomers, with limits of detection ranging from 0.1 to $1.3 \mu \mathrm{g} / \mathrm{mL}$. 


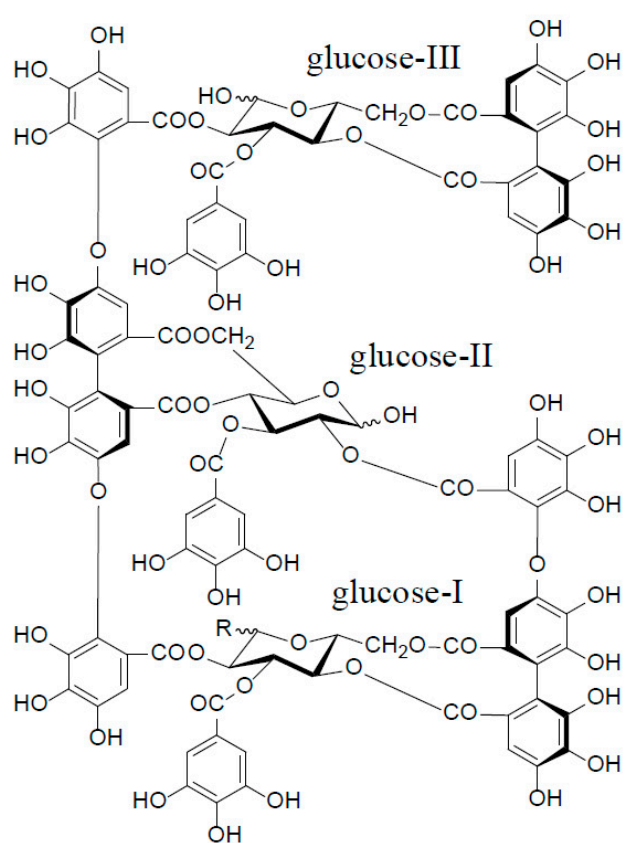

13: $\mathrm{R}=\mathrm{OH}$

14: $\mathrm{R}=\alpha-\mathrm{OG}$

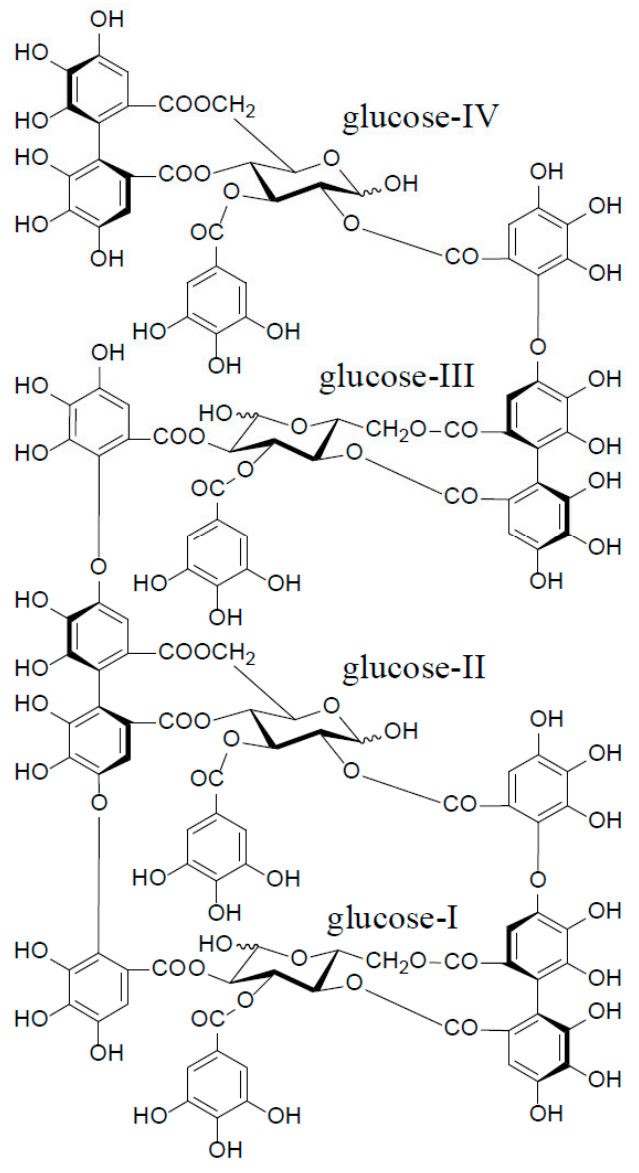

16
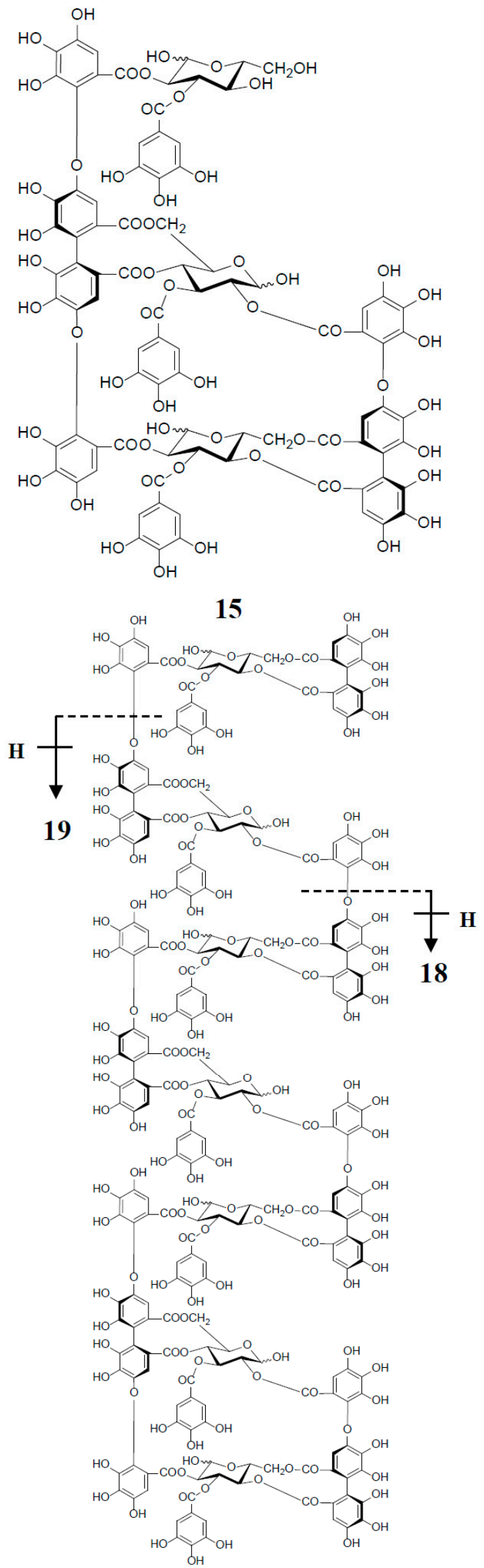

20

Figure 4. Cont. 


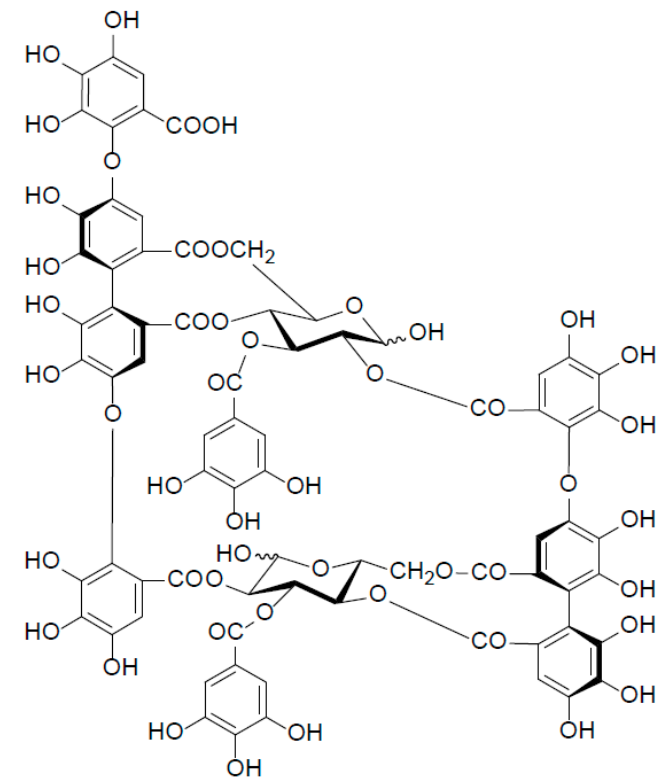

17

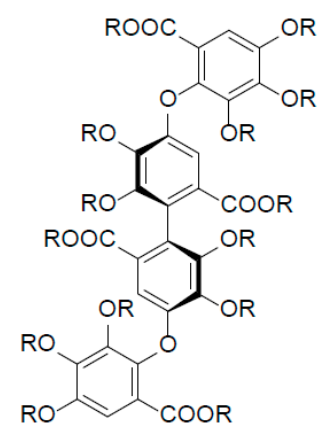

21: $\mathrm{R}=\mathrm{H}$

21a: $\mathrm{R}=\mathrm{Me}$

Figure 4. Structures of oenothein A (13), woodfordins D (14), E (15), and F (16), pentamer (18), hexamer (19), and heptamer (20), Structures of woodfordin I (17) and woodfordinic acid (21).

Woodfordinic acid (21), which is the parent acid participating in the linkage of three glucose cores (I-III) in oenothein A (13) and woodfordin D (14), was characterized as a gallic acid tetramer by spectral analyses (NMR, MS, and CD) of its methylated derivative $\left(21 \mathrm{a} ; \mathrm{C}_{42} \mathrm{H}_{46} \mathrm{O}_{20}\right)$ obtained upon permethylation of 14 followed by methanolysis [21]. Its symmetrical structure was evidenced by 2 aromatic proton singlets and 7 methoxy proton signals, and 21 carbon signals comprising of $12 s p^{2}$, 2 ester carbonyl and $7 s p^{3}$ carbon signals in the ${ }^{1} \mathrm{H}$ - and ${ }^{13} \mathrm{C}-\mathrm{NMR}$ spectra, respectively (Figure 4). Woodfordin I (17), a dimer possessing the woodfordinoyl group, is likely a catabolic metabolite of 13 and 14. Interestingly, woodfordin I was also isolated from a traditional Chinese medicine, Chamaenerion (= Epilobium) angustifolium [24].

Analogs eugeniflorin $\mathrm{D}_{2}(22)$, and oenotherin $\mathrm{T}_{1}$ (23) and $\mathrm{T}_{2}$ (24), all containing an oxidized valoneoyl group, were found in Eugenia uniflora [15] and O. tetraptera [25,26], respectively. The structural confirmation of oenotherin $\mathrm{T}_{1}$ (23) was conducted by the $\mathrm{Na}_{2} \mathrm{~S}_{2} \mathrm{O}_{4}$ reduction of the isodehydrovaloneoyl group affording oenothein A (13), similar to the conversion of a dehydrohexahydroxyl group to an HHDP group [3]. Notably, in contrast to many Oenothera species producing mainly oenothein A (13) and B (4), the most abundant constituent of $O$. tetraptera was oenotherin $\mathrm{T}_{1}$. On the other hand, eugeniflorin $\mathrm{D}_{2}(\mathbf{2 2})$, with a dehydrovaloneoyl group isomeric to that in oenotherin $\mathrm{T}_{1}$ (23), was also found in the leaves of Eucalyptus cypellocarpa [27] and Myrtus communis of Myrtaceae [28]. Eurobustin C (25), isolated from Eucalyptus robusta [6], as well as oenotherin $\mathrm{T}_{2}$ (24), had a new unique linking unit in place of the valoneoyl group, as shown in Figure 5.

In a study on the production of ellagitannins by callus cultures, Taniguchi et al. reported the establishment of callus tissues induced from the Oenothera laciniata leaves, which yielded large amounts of oenotheins A (13) and B (4), as well as oenotherin $T_{1}$ (23) [25,29]. It is noteworthy that oenothein B content $(65 \mathrm{mg} / \mathrm{g}$ dry wt) in the calli cultured on modified Linsmaier-Skoog's medium was 1.8 times higher than that of intact leaves [29]. 


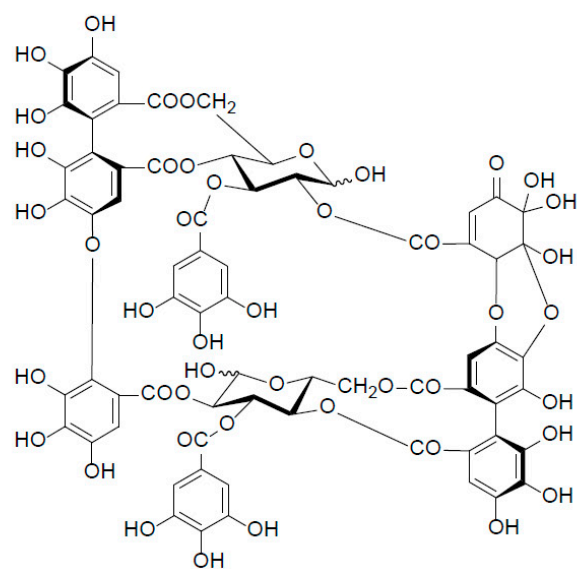

22

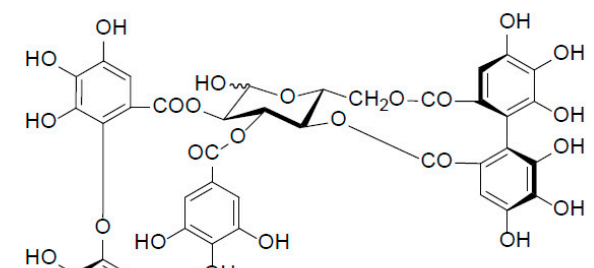

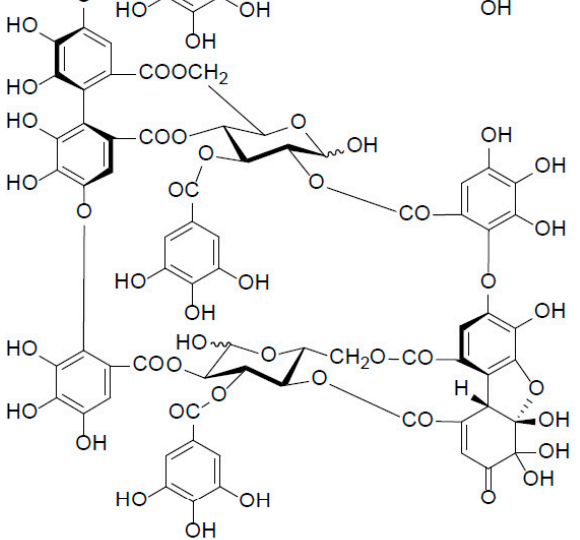

23

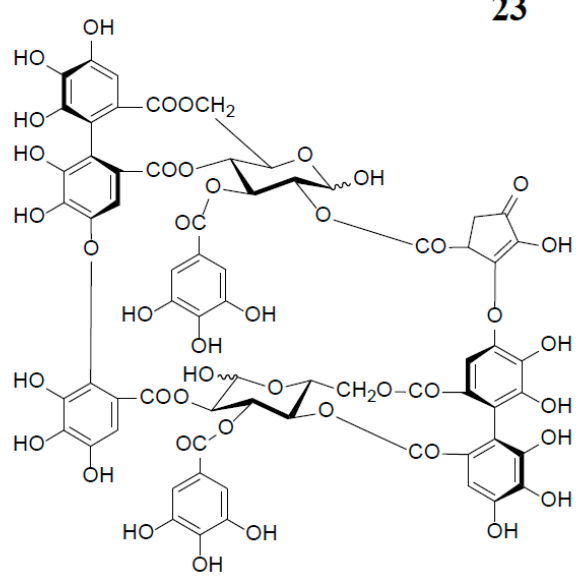

25

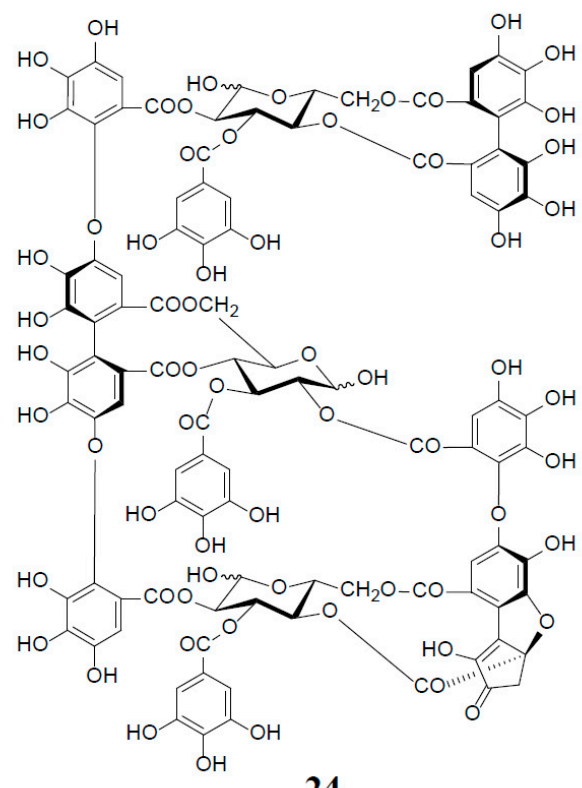

24

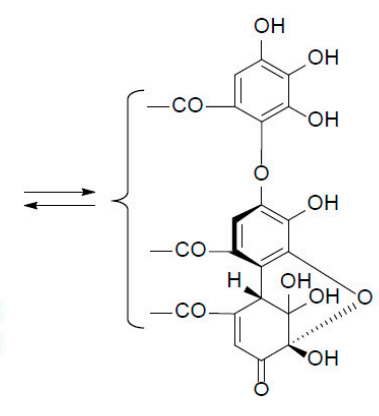

Figure 5. Structures of eugeniflorin $\mathrm{D}_{2}$ (22), oenotherins $\mathrm{T}_{1}(\mathbf{2 3}), \mathrm{T}_{2}(\mathbf{2 4})$, and eurobustin $\mathrm{C}(\mathbf{2 5})$.

\section{Distribution of Oenothein B and Its Analogs}

As described earlier, oenotheins A (13) and B (4) have been isolated as main ingredients accompanying various analogs from the plant species of Onagraceae, Lythraceae, and Myrtaceae [5,10,11,20,30,31]. 
The distribution of oenothein B (4) in further species of these plant families was examined by HPLC to reveal its considerable wide occurrence, particularly in Eucalyptus species of Myrtaceae [30,32]. The oenothein B-containing plants reported so far are summarized in Table 1. Recently, the dried pericarps of Punica granatum belonging to Lythraceae (Punicaceae) were reported to produce oenothein B, along with new tellimagrandin I-based linear oligomers, pomegraniin A (tetramer) (28) and $\mathrm{B}$ (pentamer) (29), as well as eucalbanin B (dimer) (26) and eucarpanin $\mathrm{T}_{1}$ (trimer) (27), which were first isolated from the leaves of Eucalyptus alba [33] and E. cypellocarpa [27] (Myrtaceae), respectively [34] (Figure 6). Although in the classical plant taxonomy Punicaceae belonged to its own family, it is currently included in the Lythraceae family in the phylogenetic system APG III [35]. It is chemotaxonomically interesting that the oligomeric ellagitannins of P. granatum showed close resemblance with those of the genera Cuphea, Lythrus, and Woodfordia, which are closely related genera in this family [36], although P. granatum is distinguished from the species of the other genera in the elongation mode of the monomers; that is, the presence of an oenothein B-based trimer (13) in the latter three, or absence in the former.

Table 1. Distribution of oenothein B and related macrocyclic oligomers in plants.

\begin{tabular}{|c|c|c|}
\hline Family Species & Tannins & Ref. \\
\hline \multicolumn{3}{|l|}{ Oenotheraceae } \\
\hline Oenothera erythrosepala Bordas & oenothein B & [9] \\
\hline O. biennis L. & oenotheins A, B & {$[20,37,38]$} \\
\hline O. laciniata Hill. & oenotheins A, B, D, F, G & [12] \\
\hline O. tetraptera Cav. & oenotheins $\mathrm{A}, \mathrm{B}$, oenotherins $\mathrm{T}_{1}, \mathrm{~T}_{2}$ & {$[25,26]$} \\
\hline O. paradoxa Hudziok & oenothein B & [38] \\
\hline Epilobium capense Buch. & oenotheins A, B & {$[10,11]$} \\
\hline E. angustifolium L. & oenotheins A, B, woodfordin I, tetramer-heptamer & {$[10,11,22,24,39]$} \\
\hline E. pyrricholophum Franch. et Sav. & oenotheins B & [39] \\
\hline E. hirsutum L. & oenotheins B & {$[10,39]$} \\
\hline E. palustre L. & oenotheins A, B & [39] \\
\hline E. dodonoei Vill. & oenothein B (HPLC) * & [10] \\
\hline E. stereophyllum Fres. & oenothein B (HPLC) & [10] \\
\hline E. salignum Hausskn. & oenothein B (HPLC) & [10] \\
\hline E. parviflorum Schreb. & oenothein B (HPLC) & [10] \\
\hline E. roseum Schreb. & oenothein B (HPLC), (LC/MS) * & {$[10,11]$} \\
\hline E. tetragonum $\mathrm{L}$. & oenothein B (LC/MS) & [11] \\
\hline E. montanum $\mathrm{L}$. & oenothein B (HPLC), (LC/MS) & {$[10,11]$} \\
\hline \multicolumn{3}{|l|}{ Lythraceae } \\
\hline Lythrum anceps Makino & oenothein B & [31] \\
\hline Woodfordia fruticosa Kurz. & oenotheins A, B woodfordins C D E. E I & {$[13,14,20,211$} \\
\hline Cuphea hyssopifolia Humb. & oenotheins $A, B$, woodfordin $C$, cuphiins $D_{1}, D_{2}$ & $\begin{array}{c}[10,16], 21] \\
{[16]}\end{array}$ \\
\hline Punica granatum L. & oenothein B & {$[34]$} \\
\hline \multicolumn{3}{|l|}{ Myrtaceae } \\
\hline Eugenia uniflora L. & oenothein $B$, eugeniflorins $D_{1}, D_{2}$ & {$[15,40]$} \\
\hline Melaleuca leucadendron $\mathrm{L}$. & oenothein B & [5] \\
\hline Myrtus communis L. & oenothein $B$, eugeniflorin $D_{2}$ & {$[28]$} \\
\hline Eucalyptus alba Reinw. Ex Blume & oenothein B & [33] \\
\hline E. robusta $\mathrm{Sm}$. & oenothein $B$, eugeniflorin $D_{2}$, eurobustin $C$ & {$[27]$} \\
\hline E. cypellocarpa LAS Johnson & oenothein $B$, eugeniflorin $D_{2}$ & [27] \\
\hline E. globulus Labill. & oenothein B & {$[30]$} \\
\hline E. consideniana Maiden & oenothein B & {$[32]$} \\
\hline E. viminalis Labill. & oenothein B & [32] \\
\hline E. pulverulenta Sims. & oenothein B (HPLC) * & {$[30]$} \\
\hline E. nicholii Box Hill. Merbourne & oenothein B (HPLC) & [30] \\
\hline E. camaldulensis Dehnh. & oenothein B (HPLC) & [30] \\
\hline Myrtus communis var. microphylla Willk. & oenothein B (HPLC) & [30] \\
\hline Austromyrtus dulcis L.S. Sm. & oenothein B (HPLC) & [30] \\
\hline
\end{tabular}

${ }^{*}$ Method for identification, characterization, or detection. 


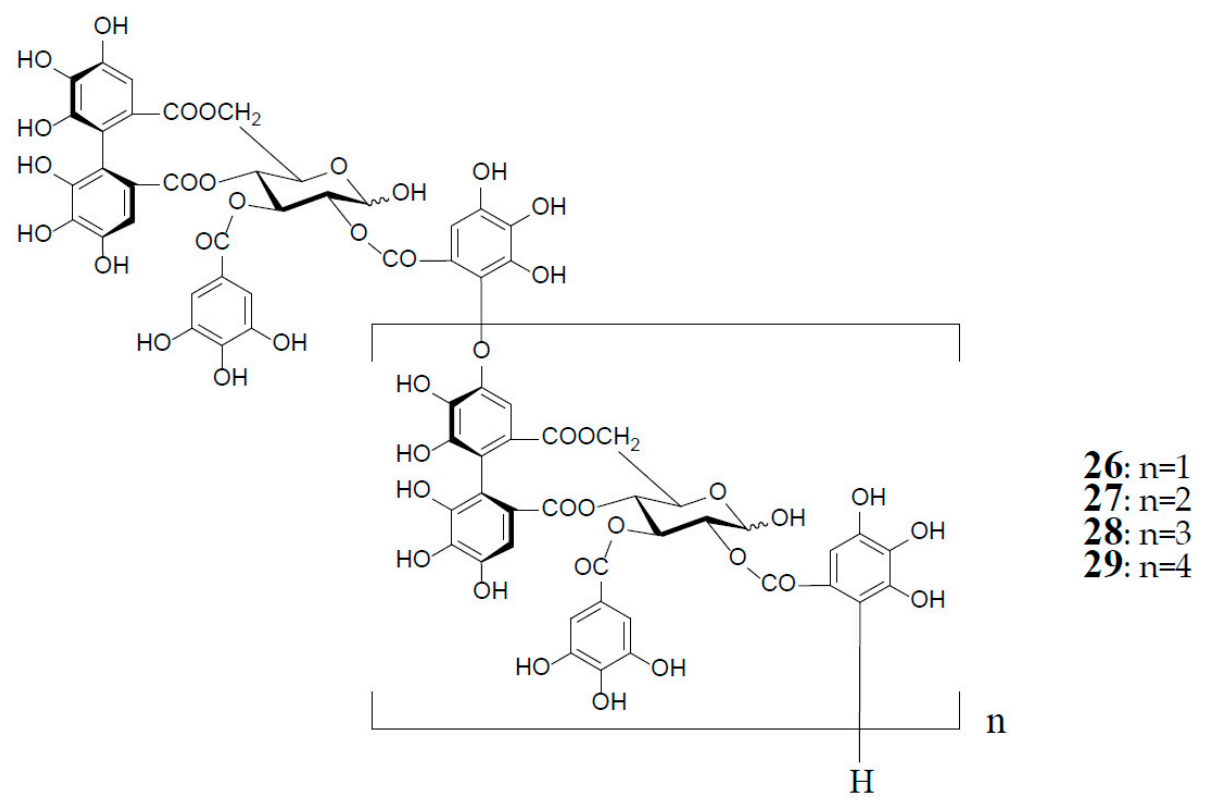

Figure 6. Structures of eucalbanin B (26), eucarpanin $T_{1}$ (27), pomegraniin A (tetramer) (28), and B (pentamer) (29).

\section{Biological Activities of Oenothein B and Related Oligomers}

Numerous medicinal plants rich in tannins have long been used worldwide as folk medicines or traditional medicines for various purposes, represented by antidiarrheic, hemostatic, and the treatment of gastrointestinal disorders, wound healing, and skin stress $[4,7]$. The active components of these plant extracts responsible for such therapeutic effects were ascribed to the tannins (large molecular polyphenols), which were long recognized to have non-specific binding ability with proteins (astringency), inducing a peristaltic action. However, the remarkable progress in the structural characterization of ellagitannin constituents in those medicinal plants since the 1980s has enabled studies on various pharmacological activities of individual tannin constituents with defined structures. As a result, diverse biological effects, such as antioxidant, antimicrobial, antitumor, antiulcer, and anti-inflammatory effects, have been found by various in vitro and in vivo studies $[4,6,7]$ and citations therein [41]. The efficacies of such biological activities have been reported to be largely dependent on the difference of types or structures of tannins and related polyphenols, and on their concentrations. Advance in the structural study of ellagitannins also has enabled investigation of the interaction between structure-defined ellagitannins and certain proteins, amino acids, or metals. These studies revealed that tannin-protein complex formations are not due to nonspecific binding with proteins, as previously thought, but largely dependent on the structure and concentration of tannins and targeted proteins. Recently, the importance of molecular size and structural flexibility of ellagitannins in the interaction with bovine serum albumin was emphasized, based on the thermodynamic study of the interaction using isothermal titration calorimetry and fluorescence spectroscopy [42].

As oenothein B (4) constitutes a unique class of ellagitannins in its macrocyclic structure with limited flexibility of rotational bond, and also in its high content in many medicinal Oenothera, Epilobium, and Eucalyptus species, its biological activities have been widely studied [5-7,39,43]. Among such pharmacological effects, hitherto documented for oenothein B and its analogs, this review summarizes selected papers, reporting (1) antioxidant and anti-inflammation activity; (2) antitumor activity; (3) immunomodulatory effects; and (4) antimicrobial effects, including our recent findings. 


\subsection{Antioxidant and Anti-Inflammation Activity}

The active oxygen damage or formation of reactive oxygen species (ROS), caused by an imbalance in the body's antioxidant system, has been related with the pathogenesis of various human diseases, such as cancer and cardiovascular diseases, and inflammation [44]. Antioxidant activity is the most basic biological property of polyphenols, ranging from flavonoids and lignans of small molecules to tannins of higher molecular weight $[4,7,45]$. Okuda's early in vitro studies on the antioxidant effects of polyphenols estimated by (1) 1,1-diphenyl-2-picrylhydrazyl (DPPH) radical scavenging test, (2) $\mathrm{Cu}$ (II)-catalyzed autoxidation of ascorbic acid, and (3) lipid peroxidation in rat liver mitochondria and microsomes, demonstrated that the antioxidative potencies of ellagitannins, including oligomers, were generally higher than those of small molecular polyphenols, as well as $\alpha$-tocopherol and ascorbic acid [46].

These properties are ascribable to the potent radical scavenging ability of ellagitannins, which can terminate free radical chain reaction of other compounds, e.g., lipid peroxidation, by their self-oxidation, thus preventing the oxidation of lipids, proteins, or DNA. A stable radical of an ellagitannin, geraniin (1), generated upon air oxidation in an alkaline DMSO solution, was substantiated by the observation of its free radical signals with modulation width $0.05 \mathrm{G}$ in the ESR spectrum [47]. The reactivity of a phenolic radical generated upon donating a phenolic hydrogen radical to another free radical (ROS) was indicated by the treatment of an alkyl gallate with DPPH radical, which produced a dialkyl ester of hexahydroxydiphenic acid by mutual coupling of transient C-centered galloyl radicals [48] (Figure 7). This radical coupling reaction is reminiscent of the ellagitannin biosynthesis by laccase-like enzymes, as described earlier.

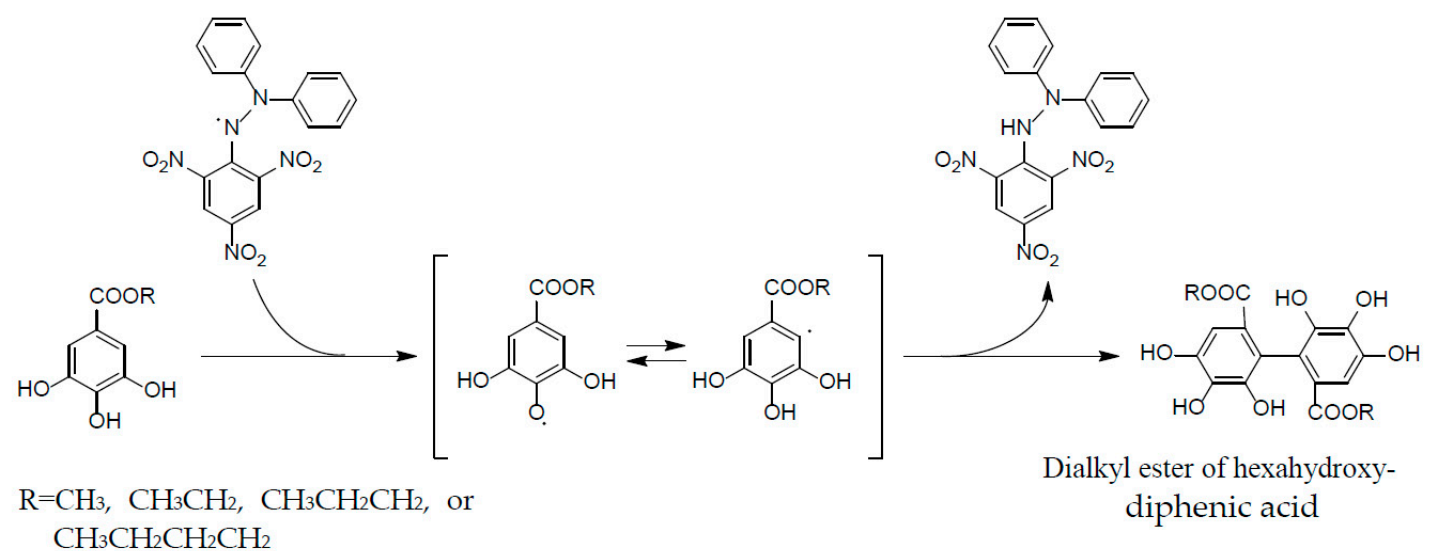

Figure 7. Formation of dialkylester of hexahydroxydiphenic acid in radical reaction of alkyl gallate with DPPH.

The biological antioxidant efficacies of representative condensed tannins, hydrolysable tannins, and related simple phenolics, such as catechin, methyl gallate, and pyrogallol, were also evaluated by cyclic voltammetry. In these studies, the redox potentials of all polyphenols at $\mathrm{pH}$ 6-8 were reported to be substantially below $1000 \mathrm{mV}$, thus implicating that they act as reducing agents (radical scavengers) for the peroxyl $\left(E^{-1} 1000 \mathrm{mV}\right)$ and hydroxyl $\left(E^{-} 2300 \mathrm{mV}\right)$ radicals [49].

Although these redox potentials of the tannins were similar to those of simple polyphenols, tannins were 15-30 times more effective at quenching peroxyl radicals than simple phenolics or Trolox (6-hydroxy-2,5,7,8-tetramethyl-chroman-2-carboxylic acid) in a metmyoglobin assay [50]. This result suggests a significance of high molecular weight and the proximity of many aromatic rings and hydroxyl groups for the free radical scavenging ability.

Antioxidant and anti-inflammatory effects of oenothein B-rich Epilobium and Oenothera species against oxygen stress have been studied, in order to justify their traditional usages as herbal supplements or tea $[11,37,38,51]$. Epilobium species (willowherbs) have long been used to improve 
urogenital functions (prostate, bladder, and hormone troubles) in European folk medicine. The extracts of the three most popular Epilobium species (E. angustifolium, E. hirsutum, and E. parviflorum), which contained oenothein B (4) in high quantities (20-35\%), exhibited inhibitory effects on lipoxygenase and hyaluronidase, with $\mathrm{IC}_{50}$ around $25 \mu \mathrm{g} / \mathrm{mL}$ and $5 \mu \mathrm{g} / \mathrm{mL}$, respectively. Additionally, the radical scavenging properties of these extracts were demonstrated by the significant reduction of ROS generated from $\mathrm{N}$-formyl-methionyl-leucyl-phenylalanine (f-MLP) and phorbol myristate acetate (PMA)-induced neutrophils, with $\mathrm{IC}_{50} 5 \mu \mathrm{g} / \mathrm{mL}$ and $25 \mu \mathrm{g} / \mathrm{mL}$, respectively. A plausible active constituent responsible for these activities was considered as the predominant oenothein B. In fact, oenothein $\mathrm{B}(4)$ inhibited myeloperoxidase (MPO) release from stimulated neutrophils with $\mathrm{IC}_{50}$ $7.7 \mu \mathrm{M}$, similarly to the anti-inflammatory drug indomethacin $\left(\mathrm{IC}_{50} 15.4 \mu \mathrm{M}\right)$, and hyaluronidase with $\mathrm{IC}_{50} 1.1 \mu \mathrm{M}[39,51]$. Similarly, Kiss et al. reported that extracts of Oenothera paradoxa and O. biennis exhibited anti-inflammatory activity by inhibiting hyaluronidase and lipoxygenase in a concentration-dependent manner, and an inhibitory effect against ROS production from human neutrophils [37,38]. The antioxidant property of extracts from the most common Epilobium species, all of which were shown to be rich in oenothein B (4) as estimated by LC/MS, were measured by a simple spectrophotometric method using 2,2'-azinobis-(3-ethylbenzthiazoline-6-sulfonic acid) (ABTS), and the extract of E. parviflorum was shown to have the highest radical-scavenger activity among these extracts, and comparable to that of well-known antioxidants, Trolox and ascorbic acid [11].

\subsection{Antitumor Effect}

\subsubsection{Cytotoxicity against Tumor Cell Lines}

Tumor cell growth is regulated in the balance between proliferation and apoptosis. There is considerable amount of evidence indicating that ellagitannins reduce the growth of cancer cells by inhibiting cell proliferation and inducing apoptotic cell death.

In in vitro studies of macrocyclic ellagitannins performed with cancer cell lines, oenothein B (4), woodfordin $C(5)$, and cuphiins $\mathrm{D}_{1}(8)$ and $\mathrm{D}_{2}$ (7) significantly inhibited the growth of the human oral epidermoid (KB), cervical (HeLa), prostate carcinoma (DU-145), and hepatocellular (Hep-3B) carcinoma cell lines, and the promyelocytic leukemia (HL-60) cell lines, and showed less cytotoxicity than adriamycin against a normal cell line (WISH) [52]. The mechanism for the cyctotoxicity of cuphiins $\mathrm{D}_{1}(\mathbf{8})$ was examined using HeLa cell lines, and was suggested to be due to induction of apoptosis by inhibition of Bcl-2 expression [53]. Moreover, oenothein B, woodfordin C (5) and D (14) showed higher cytotoxic activity against human oral squamous cell carcinoma and salivary gland tumor cell lines than against normal human gingival fibroblasts. These cytotoxicities were also indicative of induction of apoptotic cell death as characterized by DNA fragmentation and cleavage of cytokeratin 18 by activated caspase(s) $[27,54]$. Woodfordin I (17) suppressed the proliferation and induced apoptosis in human chronic myelogenous leukemia K 562 cells, which was mediated through the intrinsic mitochondria-dependent pathway [24].

\subsubsection{Antitumor Effect Caused by Tumor-Related Enzyme Inhibition}

Activity-guided fractionation of the bioactive components of Epilobium capense led to the isolation and identification of oenotheins A (13) and B (4) as potent inhibitors of $5 \alpha$-reductase and aromatase, enzymes involved in the etiology of benign prostatic hyperplasia. Potencies of the inhibitory effects against $5 \alpha$-reductase were $\mathrm{IC}_{50} 1.24 \mu \mathrm{M}$ for oenothein A (13) and $\mathrm{IC}_{50} 0.44 \mu \mathrm{M}$ for oenothein B (4), respectively, although they were substantially weaker than the positive control finasteride, with $\mathrm{IC}_{50}$ $5 \mathrm{nM}$. On the other hand, against aromatase, oenotheins A (13) and B (4) displayed 70\% and 33\% inhibition at $50 \mu \mathrm{M}$, respectively, higher and comparable with the synthetic reference compound aminoglutethimide (37\% inhibition at $50 \mu \mathrm{M})$ [10]. Similarly, oenothein B (4) from E. angustifolium was found to be specifically able to induce neutral endopeptidase in prostate cancer PC-3 cells, which inactivates growth stimulatory neuropeptides [55]. This enzyme is also known to be involved 
in prostate cancer progression. Thus, these results might offer a pharmacological explanation for the use (improvement of prostate diseases) of Epilobium extract as a folk medicine. As the bioavailability of oenothein B (4) still remains unsolved, Kiss et al. further investigated the consistency between the in vitro and in vivo effects of E. angustifolium (EA) aqueous extract, using LNCaP human prostate carcinoma cells (in vitro) and rats intraperitonially implanted with LNCaP cells (in vivo) [56]. EA extract $(20,50,70 \mu \mathrm{g} / \mathrm{mL})$ and oenothein B (4) $(2,5,10 \mu \mathrm{M})$ showed a significant reduction of proliferation of LNCaP cells in dose-dependent manner without affecting the normal human skin fibroblast cells, which was correlated with the induction of apoptosis. These effects were indicated to be comparable to reference compound camptothecin. Similar reduction of the prostatic adenoma up to $13 \%$ was observed upon oral administration of EA extract (50-200 mg/ $\mathrm{kg}$ ) to rats implanted with LNCaP cells, suggesting significant and consistent effects in the in vitro and in vivo assays. In order to characterize active metabolites of EA extract (oenothein B) produced by intestinal bacteria, the urinary metabolites obtained from rat and human volunteers supplemented with EA extract were investigated by an application of UHPLC-DAD-MS/MS analysis of ellagitannin metabolites, such as urolithins [57]. Although any bioactive metabolites of oenothein B remained uncharacterized, oenothein B metabolism was suggested to be obviously different from those of other ellagaitannins [56].

In a screen conducted to find inhibitors of DNA topoisomerase-II (topo-II), woodfordin C (5) isolated from the leaves of Woodfordia fruticosa [14] was shown to inhibit topo-II dose dependently [58]. This in vitro potency was much stronger than those of the clinically used drugs, adriamycin (ADR) and etoposide (ETP). This compound inhibited DNA synthesis, rather than RNA and protein synthesis, in a similar way to ETP. Upon evaluation against cultured human tumor cell lines, woodfordin C (5) showed remarkable antitumor activity $\left(\mathrm{IC}_{50} 0.07 \mu \mathrm{g} / \mathrm{mL}\right)$ against PC-1 (lung carcinoma) cells, and moderate activity against MKN 45 (stomach cancer) ( $\mathrm{IC}_{50} 1.73 \mu \mathrm{g} / \mathrm{mL}$ ) and $\mathrm{KB}$ cells $\left(\mathrm{IC}_{50} 5.58\right.$ $\mu \mathrm{g} / \mathrm{mL})$, in comparison with ADR and ETP $\left(\mathrm{IC}_{50} 0.12-0.67 \mu \mathrm{g} / \mathrm{mL}\right)$. Also, in vivo antitumor activity of woodfordin $\mathrm{C}$ (5) against colon 38 (mouse colon adenocarcinoma), subcutaneously inoculated to the flank of a $\mathrm{BDF}_{1}$ mouse was shown by $55 \%$ inhibition of tumor growth, 16 days after i.v. administration of 5 with $1.5 \mathrm{mg} / \mathrm{kg} /$ day (once daily for 5 consecutive days). This result suggested that antitumor mechanism may be through the inhibition of topo-II [58]. It is noted in the literature that 5 may not be taken directly into tumor cells, because of its large molecular mass and a high anionic charge, thus, further studies on bioavailability of 5 , as well as 4 , are still needed.

Epstein-Barr virus (EBV) is a human B lymphotropic herpes virus known to be closely associated with nasopharyngeal carcinoma (NPC). Inhibitory activity against EBV-DNA polymerase, which is a key enzyme during EBV replication, was estimated for the macrocyclic dimers, eugeniflorin $\mathrm{D}_{2}(22)$ and oenothein B (4), isolated from Eugenia uniflora, and the former (22) exhibited a remarkable inhibition with $\mathrm{IC}_{50} 3.5 \mu \mathrm{M}$, while the latter (4) showed weaker activity with $\mathrm{IC}_{50} 62.3 \mu \mathrm{M}$ in comparison with a positive control, phosphonoacetic acid (EBV replication inhibitor) (IC $5016.4 \mu \mathrm{M})$ [40].

On the other hand, degradation of poly(ADP-ribose) on specific chromosomal proteins in eukaryotic cells, mainly by poly(ADP-ribose) glycohydrolase, is considered to be an important factor in the regulation of gene activation, DNA replication and transcription, and cell death [59]. In a search for potent and specific inhibitors of poly(ADP-ribose) glycohydrolase purified from human placenta, oligomeric ellagitannins were found to be more potent inhibitors $\left(\mathrm{IC}_{50} 0.3-7.1 \mu \mathrm{M}\right)$ than condensed tannins and monomeric hydrolysable tannins ( $\left.\mathrm{IC}_{50} 15.5-31.8 \mu \mathrm{M}\right)$, and also than the previously known inhibitors, daunomycin and ethadridine ( $\mathrm{IC}_{50}$ 50-100 $\mu \mathrm{M}$ ), and cAMP (IC 50 5-10 mM) [60]. The most potent inhibitory activity was exhibited by nobotanin $\mathrm{K}$ (a tetramer from Tibouchina semidecandra; Melastomataceae [61]) and oenothein B (4), with $\mathrm{IC}_{50} 0.3$ and $1.8 \mu \mathrm{M}$, respectively, on a molar concentration basis. It is notable that the condensed tannins (epicatechin gallate dimer to tetramer) and flavan-3-ols tested were not active even at $100 \mathrm{mM}$. As depoly(ADP-ribosyl)ation of chromosomal proteins was suggested to be involved in the initiation of glucocorticoid-sensitive mouse mammary tumor virus (MMTV) transcription, the inhibitory effect of oenothein B (4) on MMTV gene expression in intact 34I cells, derived from $\mathrm{C} 3 \mathrm{H}$ mouse mammary carcinoma, was examined. 
As a result, pretreatment with oenothein B (4) potently suppressed, dose-dependently in a range of $1-50 \mu \mathrm{M}$, the induction of MMTV mRNA by dexamethasone $(100 \mathrm{nM})$. It is noteworthy that oenothein B showed no inhibitory effect against other poly(ADP-ribose) metabolizing enzymes tested, such as poly(ADP-ribose) polymerase and $\mathrm{NAD}^{+}$glycohydrolase, even at $0.5 \mathrm{mM}$, thus indicating that oenothein B is specific for poly(ADP-ribose) glycohydrolase [62]. Although poly(ADP-ribosyl)ation has been suggested to be involved in regulation of DNA repair, transcription, centrosome duplication, and chromosome stability, the regulation of the degradation of poly(ADP-ribose) and its significance remain less understood $[59,63,64]$. Therefore, oenothein B (4) may not only be a promising therapeutic candidate, but also one of the useful chemicals in pharmacological experiments for elucidation of the physiological role of poly(ADP-ribose).

\subsubsection{Host Mediated Antitumor Activity}

Detailed investigations on the host-mediated antitumor effect of ellagitannins and other related polyphenols were reported by Miyamoto and Okuda's group [65-67]. Oenothein B (4) exhibited remarkable host-mediated antitumor activity upon intraperitoneal (ip) injection several days before or after inoculation of sarcoma-180 (S-180) tumor cells into the abdomen of mice [65]. The evaluation of the activity was evaluated by the number of survivors (in six mice/group), and the percent increase in life span (\%ILS) 60 days after administration. Treatment with a $10 \mathrm{mg} / \mathrm{kg}$ dose of oenothein B (4) four days before inoculation of S-180 resulted in four survivors out of six mice, and $196 \%$ ILS, demonstrating that oenothein $\mathrm{B}$ was the most potent among the approximately 100 polyphenols tested, including condensed tannins and ellagitannins (monomers-tetramers), as well as related small molecular polyphenols, such as caffeic acid derivatives and gallotannins. Oenothein A (13) and woodfordin D (14) showed 102.7 and $123.0 \%$ ILS, respectively, and each with one survivor. Oenothein B also exhibited anticancer activity against murine mammary carcinoma MM2 in $\mathrm{C} 3 \mathrm{H} / \mathrm{He}$ mice by i.p. administration at $10 \mathrm{mg} / \mathrm{kg}$ dosage, at one, four, and seven days after the cancer inoculation. The effect evaluated after 60 days showed high \%ILS (126.8\%), and four survivors out of six mice [63]. This effect was stronger than that of OK-432, a streptococcal preparation with a potent immunostimulatory activity [68]. in vivo treatment with these antitumor-active dimers induced cytotoxic adherent peritoneal exudate cells, including stimulated macrophages producing and secreting interleukin (IL)-1 $\beta[65,67,69]$. Cuphiin $\mathrm{D}_{1}(8)$ was also shown to stimulate human peripheral blood mononuclear cells (PBMCs) and release, dose-dependently, IL-1 $\beta$, IL-2, and TNF- $\alpha$, and then activate T cells. Therefore, cuphiins $D_{1}$-activated T cells via IL-1 $\beta$, in vitro, might account for the host-mediated mechanism of 8 . Thus, the antitumor effect of these tannins was attributed to the enhancing of the immune response of the host, and not due to their direct cytotoxic action on tumor cells [70].

\subsection{Immunomodulatory Effect}

In order to understand the mechanisms underlying diverse biological activities of macrocyclic ellagitannins, such as anti-inflammatory, antitumor, and antimicrobial effects, the immunomodulatory effects of oenothein B (4) have been investigated in various in vitro or in vivo immune systems.

Oenothein B (4) was reported [71] to activate a number of phagocyte functions in an in vitro evaluation using neutrophils and monocytes purified from healthy human blood, resulting in the induction of intracellular $\mathrm{Ca}^{2+}$ flux, production of ROS, NF-kB activation, and proinflammatory cytokine production. On the other hand, intraperitoneal administration of 4 to female BALB/c mice induced significant levels of keratinocyte, which directly correlated with the neutrophil influx into the peritoneum. However, the oenothein B-related small molecular weight polyphenols, gallic acid, pyrogallol, pyrocatechol, and 3,4-dihydroxybenzoic acid, were all inactive, suggesting the necessity of the whole structure of 4 for the modulation of the phagocyte functions, both in vitro and in vivo [71]. Oenothein B (4) was also shown to reduce, dose-dependently, nitric oxide (NO) production, inducible nitric oxide synthase (iNOS) mRNA, and iNOS protein levels, without inhibiting the iNOS enzymatic activity in lipopolysaccharide (LPS)-stimulated murine RAW 264.7 macrophage 
cells [72,73]. The $\mathrm{IC}_{50}$ value of 4 for inhibition of inducible $\mathrm{NO}$ production was $17.7 \mu \mathrm{M}$, while gallic acid, a component unit of 4, showed much weaker activity, with $\mathrm{IC}_{50} 631.6 \mu \mathrm{M}$, implying the requirement of the entire structure of 4 for this effect, in agreement with the above results [71]. The inhibition of inducible NO synthesis by 4 in a dose-dependent manner was also observed in Toll-like receptor (TLR)-stimulated RAW 264.7 cells, which were stimulated using TLR4 and TLR2 agonists. Such an inhibitory effect by 4 was shown to be NF kB-dependent, but independent from the interferon (IFN)- $\gamma /$ JAK-STAT pathway [72]. As inappropriate or excessive NO production by iNOS is closely associated with numerous inflammatory diseases and neuropathic pain states, oenothein B (4) might be a promising lead for the development of therapeutic agents as the effective inhibitors of NO production. Ramstead et al. reported that oenothein B (4) stimulated innate lymphocytes, including bovine and human $\gamma \delta \mathrm{T}$ cells and NK cells, resulting in either increased CD25 and/or CD69 expression. Oenothein B thus enhanced the production of IFN $\gamma$ by bovine and human NK cells, and also by human $\mathrm{T}$ cells. These responses were not observed with other commonly studied polyphenols. Since IFN $\gamma$ is known to contribute to antitumor, antibacterial, and antiviral cell responses, these data suggested an additional mechanism for the immune-enhancing properties of oenothein B [74]. Innate immune cell responsiveness is known to be affected by aging. Then, the responsiveness of oenothein B (4) in T cells from individuals over a broad range of ages (cord blood, young, and adult donors) was estimated by measuring IFN $\gamma$ production, and clear differences depending on the ages were observed, that is, oenothein B (4) induced IFN $\gamma$ production in T cells from adult humans and cattle, but not in T cells from human cord blood and bovine calves [75].

Recently Yoshimura et al. [76] reported the significant immunomodulatory effects of oenothein B (4) on human dendritic cells (DCs), which are widely present in various tissues in contact with the external environment, such as the skin, nose, lungs, stomach, and intestines, and have critical functions in the initial immune response as antigen presenting cells. Oenothein B (4) had significant immunoregulatory effects on DCs through suppression of cell surface molecules, downregulation of cytokine production, and induction of their apoptosis. When oenothein B (4) $(25 \mu \mathrm{M}$ or $100 \mu \mathrm{M})$ was added to the cultured immature DCs (iDCs) supplemented with TNF- $\alpha$ ( $75 \mathrm{ng} / \mathrm{mL}$ ) and LPS (100 ng/mL), the expression of cell surface molecules, CD1a and CD83, was shown to be suppressed significantly at $100 \mu \mathrm{M}$ of 4 , resulting in the dysfunction of DC-mediated immune responses by the inhibition of cell maturation and subsequent antigen presentation. The suppressive effect on DCs was shown to be due to the induction of apoptosis by a flow cytometric assay. However, in the apoptosis induced by 4 , none of caspase-3/7, 8, and 9, which play crucial roles in cell apoptosis, was activated, suggesting a caspase-independent mechanism for this apoptosis. Morphological change of tannin-treated DCs was confirmed by fluorescence microscopy, showing significant nuclear condensation without DNA fragmentation, similar to that of AIF (apoptosis-inducing factor)/PARP [poly (ADP-ribose) polymerase]-dependent cell death [77]. Oenothein B also markedly suppressed the production of inflammatory cytokines, such as IL-1 $\beta$ and IL-6, in a dose-dependent manner at $25 \mathrm{mM}$ and $100 \mathrm{mM}$. Plant tannins, including condensed tannins, are generally considered to be stable in acidic conditions [78], and thus could travel unmodified, or form complexes with some inner biomacromolecules, such as proteins and dietary fiber, through the pharyngeal tube and stomach, until metabolized in the small intestine. These effects on DCs may thus be significant in the traditional usages of oenothein B- or related ellagitannin-containing medicinal plants for the treatment of a variety of inflammatory diseases.

Apart from inflammatory effects in peripheral tissues, in vivo effects of oenothein B (4) on the damage to the central nervous system due to systemic inflammation was reported by Okuyama et al. [79]. Peripherally injected LPS is reported to induce a depressive-like abnormal behavior through induction of microglial immune responses in the brain of mice [80]. In an open-field test using mice treated with LPS (i.p.) (1 mg/ $\mathrm{kg}$ mouse), orally administered (p.o.) oenothein B $(300 \mathrm{mg} / \mathrm{kg})$ showed significant increase of the locomotive activity at $24 \mathrm{~h}$ after LPS treatment, compared with that of the control group with depressive-like behavior. Immunohistochemical and 
biochemical investigation of oenothein B-administered mice indicated suppression of LPS-induced microglial activation and LPS-induced cyclooxygenase-2 production in the hippocampus and striatum of these mice. These results suggested that oenothein B has the ability to reduce neuroinflammation in the brain during systemic inflammation. Since oenothein B itself might hardly pass through the blood-brain barrier (BBB), some metabolites of 4 produced by intestinal microflora $[57,81,82]$ were considered to likely affect the peripheral inflammation, which was followed by the suppression of the inflammatory responses in the brain, although the possibility that these metabolites can pass through $\mathrm{BBB}$ and act directly in the brain as anti-inflammation agents was not excluded.

\subsection{Antimicrobial Effects}

Antimicrobial effects of ellagitannins, including antibacterial, antivirus, and antiprotozoal activities, have been documented in many papers and reviews, including those by Okuda, Haslam, and Kolodziej $[4,6,46,83,84]$. Among them, a notable activity was the synergistic effects of certain polyphenols with currently used antibiotics against drug-resistant bacteria. Many pathogenic bacteria, such as methicillin-resistant Staphylococcus aureus (MRSA), have acquired resistance to various clinical antibiotics. This worldwide problem is likely driving the development of new antibiotic drugs in an endless stream. Synergistic effects of ellagitannins, including oenothein B (4) and tellimagrandin I (2), with $\beta$-lactam antibiotics (e.g., oxacillin), were found to restore the effectiveness of these antibiotics against MRSA. When used together with these tannins, the MICs of oxacillin against MRSA strains were markedly lowered to $1 / 250$ or $1 / 500$ [85]. These results may provide one strategy for overcoming emergent bacterial resistance.

\section{Conclusions}

Since the discovery in 1990 of oenothein B (4) and woodfordin C (5), a unique class of dimeric ellagitannins with macrocyclic structures, many analogous ellagitannins (oenotheins, woodfordins, cuphiins, eugeniflorins, and oenotherins), including oxidized oligomers up to heptamer with molecular weight 5488, have been isolated from various medicinal plants belonging to Onagraceae, Lythraceae, and Myrtaceae. Their novel structures were elucidated by spectroscopic analyses (ESIMS, 1D and 2D NMR, CD) and chemical degradation. Oenothein B is commonly the most abundant constituent in plants containing this class of macrocyclic ellagitannins.

Oenothein B (4) and its analogs were documented to possess diverse in vitro and in vivo pharmacological properties, including antioxidants, antitumor, immunomodulatory, and antimicrobial effects, and their potencies were, in general, much higher than those of the related polyphenols with small molecular weight, suggesting the necessity of the entire structure of tannins for exhibiting activities. Hence, this type of oligomer may provide promising leads for the development of novel therapeutics and chemopreventive agents. An often-claimed problem is that high molecular weight tannins (polyphenols) have a limited bioavailability in biological systems due to their low solubility, stability, and membrane permeability. Therefore, biological activities of tannins and related polyphenols found in in vitro and in vivo assays have to be interpreted with caution, as noted in many papers or reviews, for the necessity of further studies. Increased interest for the fate of ellagitannins in the gastrointestinal tract has thus prompted investigations on the bioavailability or actual metabolites of ellagitannins in detail [55-57,81,82,86], and these aspects were reviewed by Tomas-Barberan et al. [87] and Torronen [88]. On the other hand, an oral delivery device, which encapsulates oenothein B or other ellagitannins, was reported for their enhanced protection through the gastrointestinal tract [89]. Further studies on these matters, including different manners of intestinal metabolism from those of non-macrocyclic ellagitannins, are strongly encouraged, for a better understanding and effective usage of these bioactive macrocyclic ellagitannins.

Author Contributions: T.Y., M.Y. and Y.A. contributed equally to this work and T.Y. finalized the manuscript.

Conflicts of Interest: The authors declare no conflict of interest. 


\section{References}

1. Haslam, E. The metabolism of gallic and hexahydroxydiphenic acid in higher plant. Fortschr. Chem. Org. Naturstoffe 1982, 41, 1-46.

2. Okuda, T.; Yoshida, T.; Hatano, T. Geraniin, a new ellagitannin from Geranium thunbergii. Tetrahedron Lett. 1976, 17, 3721-3724. [CrossRef]

3. Okuda, T.; Yoshida, T.; Hatano, T. Constituents of Geranium thunbergii Sieb. et Zucc. Part 12. Hydrated stereostructure and equilibration of geraniin. J. Chem. Soc. Perkin Trans. 1 1982, 9-14. [CrossRef]

4. Okuda, T.; Yoshida, T.; Hatano, T. Hydrolyzable tannins and related polyphenols. Prog. Chem. Organ. Nat. Prod. 1995, 66, 1-117.

5. Yoshida, T.; Amakura, Y.; Yoshimura, M. Structural Features and Biological Properties of Ellagitannins in the Myrtales. Int. J. Mol. Sci. 2010, 11, 79-106. [CrossRef] [PubMed]

6. Yoshida, T.; Hatano, T.; Ito, H.; Okuda, T. Highly Oxidized Ellagitannins and Their Biological Activity. In Plant Polyphenols 2; Gross, G.G., Hemingway, R.W., Yoshida., T., Eds.; Kluwer/Plenum: New York, NY, USA, 1999; pp. 127-144.

7. Okuda, T.; Yoshida, T.; Hatano, T.; Ito, H. Ellagitannins Renewed the Concept of Tannins. In Chemistry and Biology of Ellagitannins; Quideau, S., Ed.; World Scientific: Hackensack, NJ, USA, 2009; pp. 1-54.

8. Okuda, T.; Yoshida, T.; Kuwahara, M.; Memon, M.; Shingu, T. Agrimoniin and potentillin, ellagitannin dimer and monomer having $\alpha$-glucose cores. J. Chem. Commun. 1982, 163-164. [CrossRef]

9. Hatano, T.; Yasuhara, T.; Matsuda, M.; Yazaki, K.; Yoshida, T.; Okuda, T. Oenothein B, a Dimeric, hydrolysable tannin with macrocyclic structure, and accompanying tannins from Oenothera erythrosepala. J. Chem. Soc. Perkin Trans. 1 1990, 2735-2743. [CrossRef]

10. Ducrey, B.; Marston, A.; Göhring, S.; Hartmann, R.W.; Hostettmann, K. Inhibition of $5 \alpha$-reductase and aromatase by the ellagitannins oenothein A and oenothein B from Epilobium species. Planta Med. 1997, 63, 111-114. [CrossRef] [PubMed]

11. Tóth, B.H.; Blazics, B.; Kéry, A. Polyphenol composition and antioxidant capacity of Epilobium species. J. Pharm. Biomed. Anal. 2009, 49, 26-31. [CrossRef] [PubMed]

12. Yoshida, T.; Chou, T.; Shingu, T.; Okuda, T. Oenotheins D, F and G, Hydrolysable Tannin Dimers from Oenothera laciniata. Phytochemistry 1995, 40, 555-561. [CrossRef]

13. Yoshida, T.; Chou, T.; Nitta, A.; Miyamoto, K.; Koshiura, R.; Okuda, T. Woodfordin C, a macro-ring hydrolyzable tannin dimer with antitumor activity, and accompanying dimers from Woodfordia fruticosa flowers. Chem. Pharm. Bull. 1990, 38, 1211-1217. [CrossRef] [PubMed]

14. Kadota, S.; Takamori, Y.; Nyein, K.N.; Kikuchi, T.; Tanaka, K.; Ekimoto, H. Constituents of the leaves of Woodfordia fruticosa Kurz. I. Isolation, structure, and proton and carbon-13 nuclear magnetic resonance signal assignments of woodfruticosin (woodfordin C), an inhibitor of deoxyribonucleic acid topoisomerase II. Chem. Pharm. Bull. 1990, 38, 2687-2697. [CrossRef] [PubMed]

15. Lee, M.; Nishimoto, S.; Yang, L.L.; Yen, K.Y.; Hatano, T.; Yoshida, T.; Okuda, T. Two macrocyclic hydrolysable tannin dimers from Eugenia uniflora. Phytochemistry 1997, 44, 1343-1349.

16. Chen, L.G.; Yen, K.Y.; Yang, L.L.; Hatano, T.; Okuda, T.; Yoshida, T. Macrocyclic ellagitannin dimers, cuphiins $\mathrm{D}_{1}$ and $\mathrm{D}_{2}$, and accompanying tannins from Cuphea hyssopifolia. Phytochemistry 1999, 50, 307-312. [CrossRef]

17. Haddock, E.A.; Gupta, R.K.; Al-Shafi, S.M.K.; Layden, K.; Haslam, E.; Magnolato, D. The Metabolism of gallic acid and hexahydroxydiphenic acid in plants; biogenetic and molecular taxonomic considerations. Phytochemistry 1982, 21, 1049-1062. [CrossRef]

18. Niemetz, R.; Schilling, G.; Gross, G.G. Ellagitannin Biosynthesis: Oxidation of pentagalloylglucose to tellimagrandin II by an emzyme from Tellima grandiflora leaves. Chem. Commun. 2001, 1, 35-36. [CrossRef]

19. Niemetz, R.; Schilling, G.; Gross, G.G. Biosynthesis of dimeric ellagitannin, cornusiin E, in Tellima grandiflora. Phytochemistry 2003, 64, 109-114. [CrossRef]

20. Yoshida, T.; Chou, T.; Matsuda, M.; Yasuhara, T.; Yazaki, K.; Hatano, T.; Nitta, A.; Okuda, T. Woodfordin $\mathrm{D}$ and oenothein $\mathrm{A}$, trimeric hydrolyzable tannins of macro-ring structure with antitumor activity. Chem. Pharm. Bull. 1991, 39, 1157-1162. [CrossRef] [PubMed]

21. Yoshida, T.; Chou, T.; Nitta, A.; Okuda, T. Tannins and related polyphenols of lythraceous plants. III. Hydrolyzable tannin oligomers with macrocyclic structure and accompanying tannins from Woodfordia fruticosa KURTZ. Chem. Pharm. Bull. 1992, 40, 2023-2030. [CrossRef] 
22. Baert, N.; Karonen, M.; Salminen, J.P. Isolation, characterization and quantification of the main oligomeric macrocyclic ellagitannins in Epilobium angustifolium by ultra-high performance chromatography with diode array detection and electrospray tandem mass spectrometry. J. Chromatogr. A 2015, 1419, 26-36. [CrossRef] [PubMed]

23. Baert, N.; Kim, J.; Karonen, M.; Salminen, J.P. Inter-population and inter-organ distribution of the main polyphenolic compounds of Epilobium angustifolium. Phytochemistry 2017, 134, 54-63. [CrossRef] [PubMed]

24. Liu, M.J.; Wang, Z.; Li, H.X.; Wu, R.C.; Liu, Y.Z.; Wu, Q.Y. Mitochondrial dysfunction as an early event in the process of apoptosis induced by woodfordin I in human leukemia K562 cells. Toxicol. Appl. Pharmacol. 2004, 194, 141-155. [CrossRef] [PubMed]

25. Taniguchi, S.; Imayoshi, Y.; Yabu-uchi, R.; Ito, H.; Hatano, T.; Yoshida, T. A macrocyclic ellagitannin trimer, oenotherin $\mathrm{T}_{1}$, from Oenothera species. Phytochemistry 2002, 59, 191-195. [CrossRef]

26. Taniguchi, S.; Imayoshi, Y.; Yoshida, T.; Hatano, T. A new trimeric hydrolysable tannin, oenotherin $\mathrm{T}_{2}$, isolated from aerial parts of Oenothera tetraptera Cav. Heterocyles 2009, 79, 617-626.

27. Yoshida, T.; Hatano, T.; Ito, H. Chemistry and function of vegetable polyphenols with high molecular weights. BioFactors 2000, 13, 121-125. [CrossRef] [PubMed]

28. Yoshimura, M.; Amakura, Y.; Tokuhara, M.; Yoshida, T. Polyphenolic compounds isolated from the leaves of Myrtus communis. J. Nat. Med. 2008, 62, 366-368. [CrossRef] [PubMed]

29. Taniguchi, S.; Nakamura, N.; Nose, M.; Takeda, S.; Yabu-uchi, R.; Ito, H.; Yoshida, T.; Yazaki, K. Production of macrocyclic ellagitannin oligomers by Oenothera laciniata callus cultures. Phytochemistry 1998, 48, 981-985. [CrossRef]

30. Amakura, Y.; Yoshimura, M.; Sugimoto, N.; Yamazaki, T.; Yoshida, T. Marker constituents of the natural antioxidant Eucalyptus leaf extract for the evaluation of food additives. Biosci. Biotechnol. Biochem. 2009, 73, 1060-1065. [CrossRef] [PubMed]

31. Okuda, T.; Yoshida, T.; Hatano, T.; Yazaki, K.; Kira, R.; Ikeda, Y. Chromatography of tannins II: Preparative fractionation of hydrolyzable tannins by centrifugal partition chromatography. J. Chromatogr. A 1986, 362, 375-381. [CrossRef]

32. Santos, S.C.; Waterman, P.G. Polyphenols from Eucalyptus consideniana and Eucalyptus viminalis. Fitoterapia 2001, 72, 95-97. [CrossRef]

33. Yoshida, T.; Maruyama, T.; Nitta, A.; Okuda, T. Eucalbanins A, B and C, monomeric and dimeric hydrolyzable tannins from Eucalyptus alba REINW. Chem. Pharm. Bull. 1992, 40, 1750-1754. [CrossRef]

34. Ito, H.; Li, P.; Koreishi, M.; Nagatomo, A.; Nishida, N.; Yoshida, T. Ellagitannin oligomers and a neolignan from pomegranate arils and their inhibitory effects on the formation of advanced glycation end products. Food Chem. 2014, 152, 323-330. [CrossRef] [PubMed]

35. The Angiosperm Phylogeny Group. An update of the Angiosperm Phylogeny Group classification for the orders and families of flowering plants. APG III. Bot. J. Linn. Soc. 2009, 161, 105-121.

36. Graham, S.A.; Hall, J.; Sytsma, K.; Shi, S. Phylogenetic analysis of the Lythraceae based on four gene regions and morphology. Int. J. Plant Sci. 2005, 166, 995-1017. [CrossRef]

37. Granica, S.; Czerwińska, M.E.; Piwowarski, J.P.; Ziaja, M.; Kiss, A.K. Chemical composition, antioxidative and anti-inflammatory activity of extracts prepared from aerial parts of Oenothera biennis L. and Oenothera paradoxa Hudziok obtained after seeds cultivation. J. Agric. Food Chem. 2013, 30, 801-810. [CrossRef] [PubMed]

38. Kiss, A.K.; Kapłon-Cieślicka, A.; Filipiak, K.J.; Opolski, G.; Naruszewicz, M. Ex vivo effects of an Oenothera paradoxa extract on the reactive oxygen species generation and neutral endopeptidase activity in neutrophils from patients after acute myocardial infarction. Phytother. Res. 2012, 26, 482-487. [CrossRef] [PubMed]

39. Granica, S.; Piwowarski, J.P.; Czerwińska, E.M.; Kiss, A.K. Phytochemistry, pharmacology and traditional uses of different Epilobium species (Onagraceae): A review. J. Ethnopharmacol. 2014, 156, 316-346. [CrossRef] [PubMed]

40. Lee, M.H.; Chiou, J.F.; Yen, K.Y.; Yang, L.L. EBV DNA polymerase inhibition of 4 tannins from Eugenia uniflora. Cancer Lett. 2000, 54, 131-136. [CrossRef]

41. Yoshida, T.; Hatano, T.; Ito, H.; Okuda, T. Structural diversity and antimicrobial activities of ellagitannins. In Chemistry and Biology of Ellagitannins; Quideau, S., Ed.; World Scientific: Hackensack, NJ, USA, 2009; pp. 55-93. 
42. Dobreva, M.A.; Green, R.J.; Muller-Harvey, I.; Salminen, J.P.; Howlin, B.J.; Frazier, R.A. Size and molecular flexibility affect the binding of ellagitannins to bovine serum albumin. J. Agric. Food Chem. 2014, 62, 9186-9194. [CrossRef] [PubMed]

43. Schepetkin, I.A.; Ramstead, A.G.; Kirpotina, L.N.; Voyich, J.M.; Jutila, M.A.; Quinn, M.T. Therapeutic potential of polyphenols from Epilobium angustifolium (Fireweed). Phytother. Res. 2016, 30, 1287-1297. [CrossRef] [PubMed]

44. Jassen, Y.M.V.; Van Houten, B.; Borm, P.J.A.; Mossman, B.T. Cell and tissue responses to oxidative damage. Lab. Investig. 1993, 69, 261-274.

45. Haslam, E. Natural polyphenols (vegetable tannins) as drugs: possible models of action. J. Nat. Prod. 1996, 59, 205-215. [CrossRef] [PubMed]

46. Okuda, T.; Yoshida, T.; Hatano, T. Pharmacologically active tannins isolated from medicinal plants. In Plant Polyphenols; Hemingway, R.W., Lacks, P.E., Eds.; Plenum Press: New York, NY, USA, 1992; pp. 530-569.

47. Fujita, Y.; Komagoe, K.; Sasaki, Y.; Uehara, I.; Okuda, T.; Yoshida, T. Inhibition mechanism of tannins on $\mathrm{Cu}(\mathrm{II})$-catalyzed autoxidation of ascorbic acid. Yakugaku Zasshi 1987, 107, 17-22. [CrossRef]

48. Yoshida, T.; Mori, K.; Hatano, T.; Okumura, T.; Uehara, I.; Komagoe, K.; Fujita, Y.; Okuda, T. Radical-scavenging effects of tannins and related polyphenols on 1,1-diphenyl-2-picrylhydrazyl radical. Chem. Pharm. Bull. 1989, 37, 1919-1921. [CrossRef]

49. Hagerman, A.E.; Riedl, K.M.; Rice, R.E. Tannins as biological antioxidants. In Plant Polyphenols 2; Gross, G.G., Hemingway, R.W., Yoshida, T., Eds.; Kluwer Academic/Plenum Publishers: New York, NY, USA, 1999; pp. 495-505.

50. Hagerman, A.E.; Riedl, K.M.; Jones, G.A.; .Sovik, K.N.; Ritchard, N.T.; Hartzfeld, P.W.; Riechel, T.L. High molecular weight plant polyphenolics (Tannins) as biological antioxidants. J. Agric. Food Chem. 1998, 46, 1887-1892. [CrossRef] [PubMed]

51. Kiss, A.K.; Bazylko, A.; Filipek, A.; Granica, S.; Jaszewska, E.; Kiarszys, U.; Kośmider, A.; Piwowarski, J.P. Oenothein B's contribution to the anti-inflammatory and antioxidant activity of Epilobium sp. Phytomedicine 2011, 18, 557-560. [CrossRef] [PubMed]

52. Wang, C.C.; Chen, L.G.; Yang, L.L. Antitumor activity of four macrocyclic ellagitannins from Cuphea hyssopifolia. Cancer Lett. 1999, 140, 195-200. [CrossRef]

53. Wang, C.C.; Chen, L.G.; Yang, L.L. Cytotoxic effects of cuphiin $\mathrm{D}_{1}$ on the growth of human cervical carcinoma and normal cells. Anticancer Res. 2002, 22, 2677-2684. [PubMed]

54. Sakagami, H.; Jiang, Y.; Kusama, K.; Atsumi, T.; Ueha, T.; Toguchi, M.; Iwakura, I.; Satoh, K.; Ito, H.; Hatano, T.; et al. Cytotoxic activity of hydrolyzable tannins against human oral tumor cell lines-A possible mechanism. Phytomedicine 2000, 7, 39-47. [CrossRef]

55. Kiss, A.; Kowalski, J.; Melzig, M.F. Induction of neutral endopeptidase activity in PC-3 cell by aqueous extract of Epilobium angustifolium and Oenothein B. Phytomedicine 2006, 13, 284-289. [CrossRef] [PubMed]

56. Piwowarski, J.P.; Bobrowska-Korczak, B.; Stanislawska, I.; Bielecki, W.; Wrzesien, R.; Granica, S.; Krupa, K.; Kiss, A.N. Evaluation of the effect of Eepilobium angustifolium aqueous extract on LNCap cell proliferation in in vitro and in vivo medels. Planta Med. 2017, 83, 1159-1168. [PubMed]

57. Piwowarski, J.P.; Granica, S.; Stefarska, J.; Kiss, A.K. Differences in metabolism of ellagitannins by human gut microbiota ex vivo cultures. J. Nat. Prod. 2016, 79, 3022-3030. [CrossRef] [PubMed]

58. Kuramochi-Motegi, A.; Kuramochi, H.; Kobayashi, F.; Ekimoto, H.; Takahashi, K.; Kadota, S.; Takamori, Y.; Kikuchi, T. Woodfruticosin (woodfordin C), a new inhibitor of DNA topoisomerase II. Experimental antitumor activity. Biochem. Pharmacol. 1992, 44, 1961-1965. [PubMed]

59. Tanuma, S.; Johnson, L.D.; Johnson, G.S. ADP-ribosylation of chromosomal proteins and mouse mammary tumor virus gene expression. J. Biol. Chem. 1983, 258, 15371-15375. [PubMed]

60. Aoki, K.; Nishimura, K.; Abe, H.; Maruta, H.; Sakagame, H.; Hatano, T.; Okuda, T.; Yoshida, T.; Tsai, Y.J.; Uchiumi, F.; et al. A novel inhibitors of poly(ADP-ribose) glycohydrolase. Biochim. Biophys. Acta 1993, 1158, 251-256. [CrossRef]

61. Yoshida, T.; Haba, K.; Arata, R.; Nakata, F.; Shingu, T.; Okuda, T. Tannins and related polyphenols of Melastomataceous plants. VII. Nobotanins J and K, trimeric and tetrameric hydrolyzable tanins from Heterocentron roseum. Chem. Pharm. Bull. 1995, 43, 1101-1106. [CrossRef] 
62. Aoki, K.; Maruta, H.; Uchiumi, F.; Hatano, T.; Yoshida, T.; Tanuma, S. A macrocircular ellagitannin, oenothein $\mathrm{B}$, suppresses mouse mammary tumor gene expressionvia inhibition of poly(ADP-ribose) glycohydrolase. Biochim. Biophys. Res. Commun. 1995, 210, 329-337. [CrossRef] [PubMed]

63. Hanai, S.; Kanai, M.; Ohashi, S.; Okamoto, K.; Yamada, M.; Takahashi, H.; Miwa, M. Loss of poly(ADP-ribose) glycohydrolase causes progressive neurodegeneration in Drosophila melanogaster. Proc. Natl. Acad. Sci. USA 2004, 101, 82-86. [CrossRef] [PubMed]

64. Feng, X.; Koh, D.W. Roles of poly(ADP-ribose) glycohydrolase in DNA damage and apoptosis. Int. Rev. Cell Mol. Biol. 2013, 304, 227-281. [PubMed]

65. Miyamoto, K.; Kishi, N.; Koshiura, R.; Yoshida, T.; Hatano, T.; Okuda, T. Relationship between the structures and the antitumor activities of tannins. Chem. Pharm. Bull. 1987, 35, 814-822. [CrossRef] [PubMed]

66. Miyamoto, K.; Nomura, M.; Sasakura, M.; Matsui, E.; Koshiura, R.; Murayama, T.; Furukawa, T.; Hatano, T.; Yoshida, T.; Okuda, T. Antitumor activity of oenothein B, a unique macrocyclic ellagitannin. Jpn. J. Cancer Res. 1993, 84, 99-103. [CrossRef] [PubMed]

67. Murayama, T.; Kishi, N.; Koshiura, R.; Takagi, K.; Furukawa, T.; Miyamoto, K. Agrimoniin, an antitumor tannin of Agrimonia pilosa Ledeb., induces interleukin-1. Anticancer Res. 1992, 12, 1471-1474. [PubMed]

68. Murayama, T.; Natsuume-Sakai, S.; Ryoyama, K.; Koshiura, S. Studies on the properties of a streptococcal preparation, OK-432 (NSC-B116209), as an immunopotentiator. II. Mechanism of macrophage activation by OK-432. Cancer Immunol. Immunother. 1982, 12, 141-146. [CrossRef]

69. Miyamoto, K.; Murayama, T.; Nomura, M.; Hatano, T.; Yoshida, T.; Furukawa, T.; Koshiura, R.; Okuda, T. Antitumor activity and interleukin-1 induction by tannins. Anticancer Res. 1993, 13, 37-42. [PubMed]

70. Wang, C.C.; Chen, L.G.; Yang, L.L. in vitro immunomodulatory effects of cuphiin $\mathrm{D}_{1}$ on human mononuclear cells. Anticancer Res. 2002, 22, 4233-42336. [PubMed]

71. Schepetkin, I.A.; Kirpotina, L.N.; Jarissa, L.; Khlebnikov, A.I.; Blaskovich, C.L.; Jutila, M.A.; Quinn, M.T. Immunomodulatory activity of oenothein B isolated from Epilobium angustifolium. J. Immun. 2009, 183, 6754-6766. [CrossRef] [PubMed]

72. Schmid, D.; Gruber, M.; Piskaty, C.; Woehs, F.; Renner, A.; Nagy, Z.; Kaltenboeck, A.; Wasserscheid, T.; Bazylko, A.; Kiss, A.K. Inhibition of NF-kB-dependent cytokine and inducible nitric oxide synthesis by the macrocyclic ellagtannin oenothein B in TLR-stimulated RAW 264.7 macrophages. J. Nat. Prod. 2012, 75, 870-875. [CrossRef] [PubMed]

73. Chen, Y.; Yang, L.L.; Lee, T.J. Oroxylin A inhibition of lipopolysaccharide-induced iNOS and COX-2 gene expression via suppression of nuclear factor-kappaB activation. Biochem. Pharmacol. 2000, 59, 1445-1457. [CrossRef]

74. Ramstead, A.G.; Schepetkin, I.A.; Quinn, M.T.; Jutila, M.A. Oenothein B, a cyclic dimeric ellagitannin isolated from Epilobium angustifolium, enhances IFN $\gamma$ production by lymphocytes. PLoS ONE 2012, 7, e50546. [CrossRef] [PubMed]

75. Ramstead, A.G.; Schepetkin, I.A.; Todd, K.; Loeffelholz, J.; Berardinelli, J.G.; Quinn, M.T.; Jutila, M.A. Aging influences the response of $\mathrm{T}$ cells to stimulation by the ellagitannin, oenothein B. Int. Immunopharmacol. 2015, 26, 367-377. [CrossRef] [PubMed]

76. Yoshimura, M.; Akiyama, H.; Kondo, K.; Sakata, K.; Matsuoka, H.; Amakura, Y.; Teshima, R.; Yoshida, T. Immunological effects of oenothein B, an ellagitannin dimer, on dendritic cells. Int. J. Mol. Sci. 2013, 14, 46-56. [CrossRef] [PubMed]

77. Yu, S.W.; Wang, H.; Poitras, M.F.; Coombs, C.; Bowers, W.J.; Federoff, H.J.; Poirier, G.G.; Dawson, T.M.; Dawson, V.L. Mediation of poly(ADP-ribose) polymerase-1-dependent cell death by apoptosis-inducing factor. Science 2002, 297, 259-263. [CrossRef] [PubMed]

78. Rios, L.Y.; Bennett, R.N.; Lazarus, S.A.; Rémésy, C.; Scalbert, A.; Williamson, G. Cocoa procyanidins are stable during gastric transit in humans. Am. J. Clin. Nutr. 2002, 76, 1106-1110. [CrossRef] [PubMed]

79. Okuyama, S.; Makihata, N.; Yoshimura, M.; Amakura, Y.; Yoshida, T.; Nakajima, M.; Furukawa, Y. Oenothein B suppresses lipopolysaccharide (LPS)-induced inflammation in the mouse brain. Int. J. Mol. Sci. 2013, 14, 9767-9778. [CrossRef] [PubMed]

80. O'Connor, J.C.; Lawson, M.A.; André, C.; Moreau, M.; Lestage, J.; Castanon, N.; Kelley, K.W.; Dantzer, R. Lipopolysaccharide-induced depressive-like behavior is mediated by indoleamine 2,3-dioxygenase activation in mice. Mol. Psychiatry 2009, 14, 511-522. [CrossRef] [PubMed] 
81. Ito, H.; Iguchi, A.; Hatano, T. Identification of urinary and intestinal bacterial metabolites of ellagitannin geraniin in rats. J. Agric. Food Chem. 2008, 56, 393-400. [CrossRef] [PubMed]

82. Giménez-Bastida, J.A.; Larrosa, M.; González-Sarrías, A.; Tomás-Barberán, F.; Espín, J.C.; García-Conesa, M.T. Intestinal ellagitannin metabolites ameliorate cytokine-induced inflammation and associated molecular markers in human colon fibroblasts. J. Agric. Food Chem. 2012, 60, 8866-8876. [CrossRef] [PubMed]

83. Kolodziej, H.; Kayser, O.; Latte, K.P.; Kiderlen, A.F. Enhancement of antimicrobial activity of tannins and related compounds by immune modulatory effects. In Plant Polyphenols 2; Gross, G.G., Hemingway, R.W., Yoshida, T., Eds.; Kluwer Academic/Plenum Publishers: New York, NY, USA, 1999; pp. 575-594.

84. Kolodziej, H.; Kayser, O.; Latte, K.P.; Kiderlen, A.F.; Ito, H.; Hatano, T.; Yoshida, T.; Foo, L.Y. Antileishmanial activity of hydrolysable tannins and their modulatory effects on nitric oxide and tumor necrosis factor-a release in macrophages in vitro. Planta Med. 2001, 67, 825-832. [CrossRef] [PubMed]

85. Hatano, T.; Tsugawa, M.; Ohyabu, T.; Kusuda, M.; Shiota, S.; Tsuchiya, T.; Yoshida, T. Effects of polyphenols in tea and foods on methicillin-resistant Staphylococcus aureus and the sustainability of the antibacterial effects in the presence of food additives. Assoc. J. Jpn. Soc. Med. Use Funct. Foods 2006, 4, 43-48.

86. Ishimoto, H.; Shibata, M.; Myojin, Y.; Ito, H.; Sugimoto, Y.; Tai, A.; Hatano, T. in vivo anti-inflammatory and antioxidant properties of ellagitannin metabolite urolithin A. Bioorg. Med. Chem. Lett. 2011, 21, 5901-5904. [CrossRef] [PubMed]

87. Tomas-Barberan, F.A.; Espin, J.C.; Garcia-Conesa, M.T. Bioavailability and metabolism of ellagic acid and ellagitannins. In Chemisty and Biology of Ellagitannins; Quideau, S., Ed.; World Scientific: Hackensack, NJ, USA, 2009; pp. 273-297.

88. Torronen, R. Sources and health effects of dietry ellagitannins. In Chemisty and Biology of Ellagitannins; Quideau, S., Ed.; World Scientific: Hackensack, NJ, USA, 2009; pp. 298-319.

89. Lan, Y.; Wang, L.; Cao, S.; Zhong, Y.; Li, Y.; Cao, Y.; Zhao, L. Rational design of food-grade polyelectrolyte complex coacervate for encapsulation and enhanced oral delivery of oenothein B. Food Funct. 2017, 8, 4070-4080. [CrossRef] [PubMed] 